IZA DP No. 6476

To Meet or Not to Meet (Your Case Worker) That is the Question

Gerard J. van den Berg

Lene Kjærsgaard

Michael Rosholm

April 2012 


\title{
To Meet or Not to Meet (Your Case Worker) - That is the Question
}

\author{
Gerard J. van den Berg \\ University of Mannheim, IFAU Uppsala, \\ VU University Amsterdam and IZA
}

Lene Kjærsgaard

Aarhus University and $A K F$

\section{Michael Rosholm}

Aarhus University

and IZA

\section{Discussion Paper No. 6476 \\ April 2012}

IZA

P.O. Box 7240

53072 Bonn

Germany

Phone: +49-228-3894-0

Fax: +49-228-3894-180

E-mail: iza@iza.org

\begin{abstract}
Any opinions expressed here are those of the author(s) and not those of IZA. Research published in this series may include views on policy, but the institute itself takes no institutional policy positions.

The Institute for the Study of Labor (IZA) in Bonn is a local and virtual international research center and a place of communication between science, politics and business. IZA is an independent nonprofit organization supported by Deutsche Post Foundation. The center is associated with the University of Bonn and offers a stimulating research environment through its international network, workshops and conferences, data service, project support, research visits and doctoral program. IZA engages in (i) original and internationally competitive research in all fields of labor economics, (ii) development of policy concepts, and (iii) dissemination of research results and concepts to the interested public.
\end{abstract}

IZA Discussion Papers often represent preliminary work and are circulated to encourage discussion. Citation of such a paper should account for its provisional character. A revised version may be available directly from the author. 


\begin{abstract}
To Meet or Not to Meet (Your Case Worker) - That is the Question ${ }^{*}$

We investigate the effects of meetings between the unemployed and their case workers on the transition rate from unemployment to employment using detailed Danish event history data obtained from administrative registers. We find large positive effects of meetings. The transition rate strongly increases in the week the meeting is held, and this effect persists for some weeks after the meeting. The effect size tends to increase with the number of meetings. The effect of the first meeting on the transition rate to work does not depend on the timing of the meeting.
\end{abstract}

JEL Classification: $\quad$ C31, J64

Keywords: unemployment, active labor market policy, unemployment duration, treatment effects, meetings, job search assistance, case worker

Corresponding author:

Gerard J. van den Berg

Department of Economics

University of Mannheim

L7, 3-5

68131 Mannheim

Germany

E-mail: gerard@uni-mannheim.de

\footnotetext{
${ }^{*}$ We are grateful for comments from participants at seminars at Aarhus University, Danish Institute of Governmental Research, a Workshop on Active Labour Market Policies, Bornholm, and the Opening Workshop of the Centre for Research in Active Labour Market Policy Effects (CAFE), Ebeltoft. Kjærsgaard and Rosholm acknowledge financial support from the Danish Social Science Research Council, grant no. 275-05-0273 and the Danish Agency for Science, Technology and Innovation.
} 


\section{Introduction}

European welfare states offer a tight social safety net with generous income transfers. With a large fraction of GDP going to public spending, and a labor market with high unemployment benefits, it is a necessary condition for fiscal sustainability to have high participation and employment rates. Active labor market policies (ALMPs) play a crucial role in ensuring both the availability and a high qualification level of the labor force. The active labor market policy must serve at least three goals. First, it must provide skills for redundant unemployed workers. Second, the labor market authorities must assist the unemployed workers in finding employment as swiftly as possible. Finally, and quite importantly, it must provide sufficient incentives to search actively in order to circumvent the incentive problems generated by the generous income transfers. Thus, not only activation programs but also monitoring, sanctions, and job search assistance policies become important tools in order to achieve all these goals.

The ALMP is carried out by the case workers through meetings with the unemployed workers; therefore, meetings have several functions. They can serve to clarify the human capital deficiencies of unemployed workers and may thus be helpful in providing effective activation programs via a targeting schedule. They may also provide job search assistance to the unemployed worker, who is typically quite inexperienced at searching for employment and does not necessarily use optimal search strategies. Next, they serve as a channel for job search, in the sense that case workers have information on vacancies via access to the vacancies database of the public employment service. Finally, the meetings provide an opportunity for the case worker to test the availability and search efforts of the unemployed workers, for example, by asking/requiring the unemployed worker to document search activities (and by requiring the unemployed worker to attend the meeting). If search efforts are deemed insufficient (or the individual does not attend the meeting), the case workers can implement sanctions. For all these reasons, one might expect some "action" in the transition rates from unemployment to employment around the time of the meetings with a case worker.

In this paper we analyze how the meetings between unemployed workers and their case workers affect the transition rate to work of unemployed workers in Denmark. We use a detailed register-based data set, and we exploit random variation in the timing of meetings to identify the causal effect of a meeting or a sequence of meetings on the transition rate from unemployment to employment, using the Timing-of-Events framework (see Abbring and van den Berg (2003)). We focus in particular on how the transition rate to work depends on the time since the most recent meeting. Somewhat informally, one could argue that we take a microscopic view of the effects in the days and weeks after a meeting, and the extent to which such effect persist until the next meeting. This is informative from a policy point of view, and it sheds some light on the issue which aspects of the meetings have the largest impact. For example, monitoring effects can be expected to be more persistent than effects of specific job vacancy referrals during a meeting. 
We use unique Danish data derived from the administrative registers of the public employment services from the period January 2001 to September 2005. This allows us to construct unemployment spells and precise dates for all meetings between case workers and clients. There is a substantial amount of random variation in the timing of the meetings. Moreover, selection on unobservables is an issue of concern, and instrumental variables are not available. Hence, we can apply the Timing-of-Events approach (Abbring and van den Berg (2003)) to estimate the treatment effects of meetings attended. Moreover, using an extension of the model, we analyze the effect of sequences of meetings, and we discuss whether the timing of meetings can be improved.

We find that meetings have large positive effects on the transition rate to work (or "job finding rate"). The job finding rate increases during the week the meeting takes place, and then the effect tends to die out over time. When a second meeting is held, the job finding rate peaks at a higher level, and then the effect declines but does not disappear entirely, and for the third meeting we find even larger effects and so on. We find that the effect is of roughly the same size irrespective of the timing of the first meeting.

There have been numerous studies on the effects of various training activation programs, both in Europe and in the U.S. (see e.g. surveys by Heckman et al. (1999); Martin and Grubb (2001); Card et al. (2010), and Kluve (2010)). Recently, however, especially the European literature has started focusing on other aspects of active policies such as monitoring and sanctions, counseling and job search assistance, and the so-called threat effects (see e.g. Kluve (2010)). Our paper thus contributes to this new branch of literature, which investigates the effects of "institutional" or "administrative" labor market policies rather than traditional activation programs.

Pedersen et al. (2012) summarize the evidence from 37 studies that have analyzed the impact of meetings or aspects of meetings on various employment-related outcomes. 30 of these find significant positive effects, 7 find no significant effects, and none find negative effects of meetings. Hence, the empirical evidence on the positive effects of meetings is overwhelmingly positive, and, we would surmise, somewhat overlooked. What is absent from these studies, however, is a detailed analysis of the dynamics of the exit rates around the time of the meetings. The latter is of course the topic of the present study.

The study that is arguably most relevant and complementary to ours is Pedersen et al. (2012). They use data from a social experiment conducted in Denmark on a sample from the inflow into unemployment insurance. The treatment is the exposure to very frequent meetings with case workers. The study evaluates this regime to the standard regime, with the employment status and unemployment duration being the primary outcome measures. The meetings for the treated were so frequent that they inhibit an analysis of short-run effects in between meetings. Notice also that the evaluation of effects on hazard rates is hampered by dynamic selection even with randomization of the inflow (Abbring and van den Berg (2005)). Pedersen et al. (2012) find very large effects of fortnightly meetings during the first three months of unemployment. In the current paper we address whether meetings give rise to a higher over-all level of the hazard rate or to a pattern of spikes 
shortly after the meetings. The result of Pedersen et al. (2012) can be explained in either case.

The paper is organized as follows. In Section 2, we discuss the most relevant features, rules and regulations regarding the Danish labor market. Section 3 contains a theoretical discussion in order to frame the empirical analysis, Section 4 presents the data used in the analysis, and in Section 5, we present the econometric model used. The main results are shown in Section 6. Section 7 provides a summary and policy discussion.

\section{The Danish labor market, labor market policy, and meetings with case workers}

The Danish labor market features low costs of labor turnover and generous income transfers to compensate workers for income losses during periods without work. High labor turnover is a natural consequence of a system with low cost of hiring and firing, and, indeed, nearly one quarter of the labor force switch jobs during a year, see Frederiksen and Westergaard-Nielsen (2007). In such a flexible labor market, it is important to have a labor market policy that supports the ability of workers to make smooth transitions between jobs. Therefore, the skill enhancing and job search assistance components of labor market policies are important. The generous income transfers necessitate a labor market policy that provides the unemployed worker with sufficient incentives to search. This emphasizes the importance of frequent monitoring of job search activities, sanction policies, and certain workfare arrangements to reduce the amount of "cheap leisure" otherwise available to the unemployed workers.

Meetings between case workers and their clients - the unemployed workers - play a crucial role in ensuring that all the functions of active labor market policy measures are served. It is at the meetings that participation in activation programs are decided, job search is monitored, sanctions are imposed, job search assistance is provided, and sometimes specific job assignments are carried out.

There are five types of meetings between the unemployed workers and the case workers: CV meetings, contact meetings, job plan meetings, guidance meetings and job assignment meetings. At the CV meetings, the unemployed worker informs the case worker about previous employment, education and qualifications in general. The case worker assists the unemployed worker in producing a CV and registering various types of information. At contact meetings, the topic is job search; the possibilities and strategies of the unemployed worker to find a job immediately. Monitoring of job search, job search assistance and counseling regarding the formulation of applications may also be part of these meetings. At the job plan meetings, the unemployed worker and the case worker together produce a plan for improving the possibilities of the unemployed worker to return to employment. The job plan includes planning and scheduling of activation programs. The guidance meetings include counseling about the unemployed workers education and employment 
possibilities. At the job assignment meetings, the case worker assigns the unemployed worker to a regular job interview.

The rules of the meetings are illustrated in Figure 1. In the period 2001-2005, the unemployed worker had to attend a CV meeting during the first month of unemployment. Assignment meetings could take place at any time during the unemployment period, but would often occur in connection with other meetings. The same was the case with the guidance meetings. The unemployed worker should also participate in a job plan meeting before the assignment into an activation program. The rules of the contact meetings changed in 2003. Before 2003, the unemployed worker had to attend a contact meeting after three months but before six months of unemployment. After 2003, the unemployed worker had to participate in a least one contact meeting in the first three months of unemployment, and subsequent contact meetings were required to take place no later than three months after the last one.

Figure 1: The rules governing meetings between unemployed workers and case workers

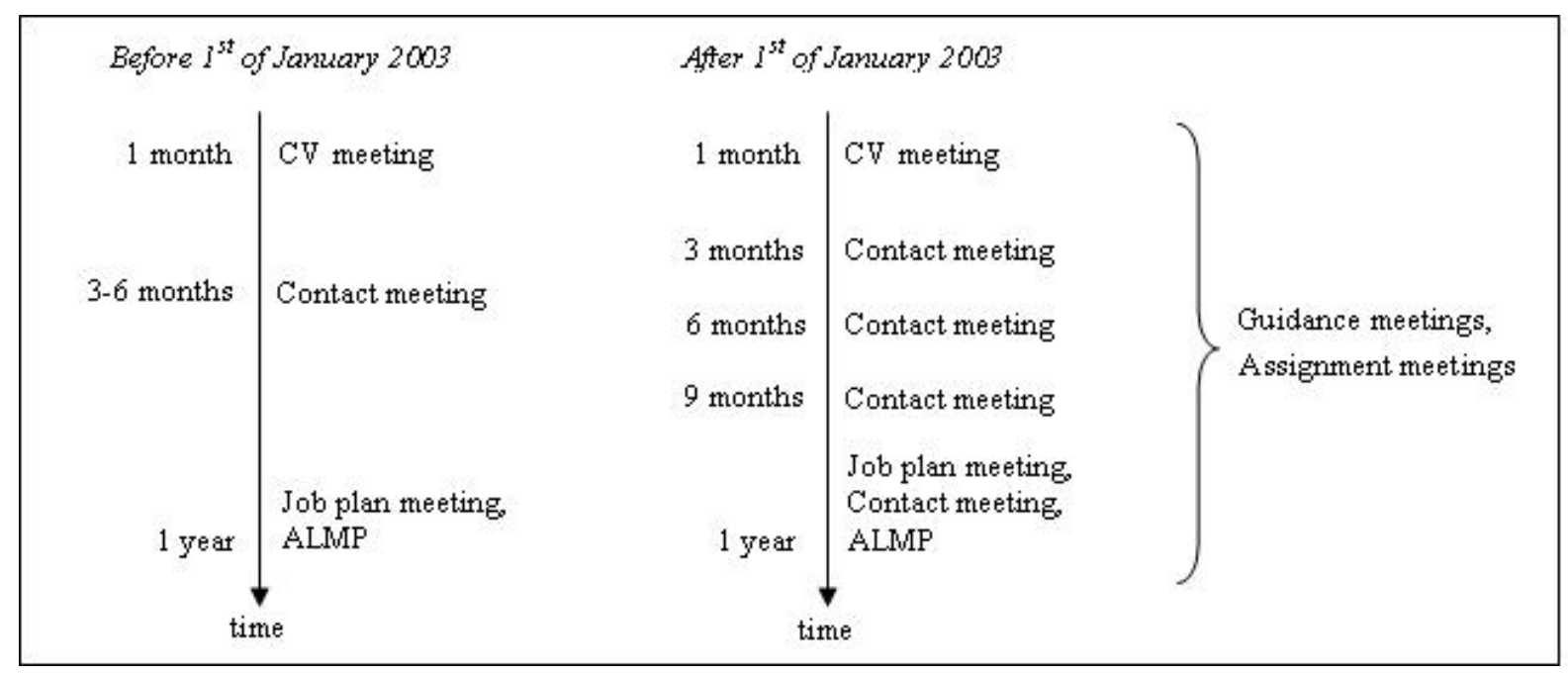

Note: The meetings should take place before the specified time, except for the contact meeting before 2003. This meeting should take place between the specified months.

The change in the rules led to increasing meeting activities; see Table 1. In the inflow to unemployment during 2000-2001, 42 percent of the unemployed had at least one meeting with their case worker during the unemployment spell while this was 74 percent for those becoming unemployed during 2003-2004. Similarly, the fraction attending multiple consecutive meetings rose from the first to the second period. For the empirical analysis it is important to make the following two remarks. First, the implementation of the change in the rules was gradual. For example, individuals in ongoing unemployment spells in January 2003 faced a slow increase in the meeting frequency for a period of at least half a year. Secondly, the period 2003-2004 faced a deterioration of labor market conditions due to a mild cyclical setback. The latter explains part of the increase in meetings, since longer unemployment durations mechanically lead to more meetings. In addition, the fact 
that the change in rules coincided with a cyclical downturn means that we cannot use the data to evaluate the change in rules.

Table 1: The distribution of the number of meetings for unemployed workers who became unemployed during 2000-1 and 2003-4, in per cent

\begin{tabular}{lcccccc}
\hline Number of meetings & At least 1 & At least 2 & At least 3 & At least 4 & At least 5 & At least 6 \\
\hline 2000 and 2001 & 42 & 25 & 15 & 9 & 6 & 4 \\
2003 and $2004^{a}$ & 74 & 49 & 31 & 21 & 15 & 11 \\
\hline
\end{tabular}

a) The period is July 1, 2003 to June 30, 2004.

Note: The numbers are for unemployed worker aged 25-50 and contain only meetings held in the first $11 / 2$ year of the unemployment spell.

Source: The Danish Economic Council (2007).

In 2007, the rules governing the meetings changed again. Now, there are only only two types of meetings: CV meetings and contact meetings. The CV meeting is unchanged. At the contact meetings the focus is is job search, monitoring, and activation planning, that is, the contact meeting has all the purposes of the previous meeting types. It was realized that the distinction was rather artificial. It was also highly endogenous and often determined/changed ex post. For these reasons we do not distinguish between types of meetings in the remainder of the paper.

In addition, we disregard CV meetings. They are held by almost all unemployed workers right at the start of the unemployment spell. Notice that this implies that the number of meetings is considerably smaller than the numbers reported in Table 1 (see Section 4).

\section{Theoretical considerations}

In this section we discuss the effects of meetings from a theoretical point of view, using a job search model of unemployed individuals. The model helps to understand the effects of a regime with meetings on individual behavior. It also provides insights into effects on the rates at which jobs are found.

First, consider an unemployed individual who searches sequentially for a job. Job offers arrive according to the rate $\lambda$. Offers are random drawings from a wage offer distribution $F(w)$. Every time an offer arrives the decision has to be made whether to accept it or to reject it and search further. During unemployment, a flow of benefits $b$ is received, possibly including a non-pecuniary utility of being unemployed. The individual aims at maximization of the expected lifetime utility over an infinite horizon. For expositional convenience, we take the wage as the only possible job characteristic and we assume that once a job is accepted it will be held forever at the same wage.

It is well known that under some regularity conditions, the optimal strategy of unemployed individuals can be characterized by a reservation wage $\phi$ giving the minimal 
acceptable wage offer. The transition rate to work $\theta$ then equals $\lambda(1-F(\phi))$.

This model can be straightforwardly extended by allowing for search effort to be a choice variable as well. In that case, if $s$ is the chosen amount of search effort per time unit, $\lambda s$ is the job offer arrival rate, $c(s)$ is the search cost flow, and the optimal strategy consists of a pair $(\phi, s)$.

As described above, the meetings between the unemployed individual and the case worker involve a combination of a few active labor market policies. For all means and purposes, these are all targeted at increasing the rate at which job offers arrive. Improving job search techniques primarily involves increasing $\lambda$, monitoring involves increasing $s$, and job vacancy referrals are supposed to involve the direct creation of an offer. Policies aimed at increasing the frequency of job offers lead to a counterreaction of the unemployed individual, since the increase in opportunities creates an incentive to be more selective vis-à-vis the quality of the offers. For example, an increase in $\lambda$ leads to an increase of the reservation wage $\phi$. Typically, the direct effect dominates the indirect effect, in the exit rate to work $\theta$ (van den Berg (1994)).

Notice that some of these policies are not restricted to the meetings alone. At the one extreme, exposure to monitoring is supposed to occur throughout the spell of unemployment and does not necessarily require personal meetings. Job search assistance is supposed to exert its positive effects throughout unemployment as well. However, job vacancy referrals are only relevant in the weeks directly after the meeting. Also, job search assistance aimed at exploiting temporary shocks in the labor market (e.g. advice on how to apply for seasonal work during the harvest season) only has a temporary effect.

Typically, data from a time interval with a more or less stable policy regime cannot be used to detect effects of non-stop exposure. In our case, for example, the monitoring regime did not change markedly during our observation interval, and monitoring occurs throughout the spell of unemployment for each individual, so that it is hard to evaluate the effect of monitoring. At the other extreme, the temporary effects of job vacancy referrals (or of meetings in general) can be studied with data on the moments of the meetings and the moment of exit out of unemployment. A job vacancy referral leads to a spike in $\theta$ in the weeks after the meeting. If the meeting actually involves a concrete job offer then, in a discrete time setting, the probability of leaving unemployment at that moment is equal to $1-F(\phi)$, whereas in the absence of the meeting it would equal $\lambda(1-F(\phi))$, where $\lambda$ is the probability of receiving an offer in a discrete-time moment. The ratio of the two equals $1 / \lambda$, which strictly exceeds 1 and which can be arbitrarily large. Institutional features may influence how long such a spike occurs. If jobs can only start at the first day of a month then the observed spike may be spread out over an interval of a few weeks beyond the moment of the meeting. If a meeting does not lead to a concrete job offer but involves job search assistance that is only relevant for a short while then again one may expect to see an elevated level of $\theta$ in the weeks following the meeting. The shorter the period in which the job search assistance is relevant, the less the individual will counteract it by being more selective. A formal analysis can be carried 
out with a non-stationary job search model (van den Berg (1990)), but it seems to be difficult to derive results on the shape of the spike in $\theta$ (e.g. whether it is symmetric) without making functional form assumptions on the wage offer distribution $F$.

Of course, meetings may give rise to interaction and accumulation effects as well. The temporary effect of a job vacancy referral may increase with successive meetings, e.g. because the case worker becomes more skilled at picking the most promising vacancies.

\section{Data}

We use a register-based 10 percent random sample of the Danish population aged 18 or more. For each individual we can construct an event history; each week, the event history indicates whether a worker is employed, unemployed, in an activation program or outside the labor force. The event history is based on information from four different registers: the Central Register of Labor Market Statistics (CRAM), the Register for Labor Market Policy Measures (AMFORA), the Coherent Social Statistics (SHS) and the Central Register of Information (CON). The data set in this study covers the period January 1, 2001 to September 30, 2005. We also have information on different socio-economics characteristics such as age, gender, education, etc. from the Integrated Database for Labor Market Research (IDA). Finally, we have information about participation in meetings with a case worker from a database (AMANDA) used for administrative purposes by the case workers and the National Labor Market Authority. All data sets used are located (and hence, the analyses carried out) on Statistics Denmark's secured servers for researchers.

The sample is limited to unemployed workers who are eligible for UI benefits (approximately 80 percent of the labor force in Denmark is a member of a UI fund and thus eligible), and who become unemployed and have the maximum (four years) of benefit eligibility. This implies that the analysis only contains people who have worked at least 52 weeks in the last three years before the current unemployment spell. In the main analysis, we focus on four groups, men and women between 30 and 50, and men and women below 30. Women and men are known to have quite different unemployment duration distributions, and the rules are applied differently to unemployed workers younger than 30 . Workers above 50 are removed from the sample to avoid behavioral effects from retirement considerations.

For each individual we define an unemployment spell as a period where the person receives UI benefits, that is, she/he is openly unemployed or participates in an activation program. The unemployment spell stops when an individual has been out of unemployment for more than four weeks. If the unemployment spell is interrupted by an employment spell shorter than four weeks, then that employment spell is treated as part of the unemployment spell (such interruptions are very often holiday payments from a previous employer). After the unemployment spell ends the individuals can either be employed or leave the labor force.

Descriptive statistics regarding sample sizes, unemployment spells, and meetings are 
shown in Table 2, and descriptive statistics for all other included explanatory variables are provided in Table A1 in the Appendix. There are 9,000-13,000 persons in each of the four samples used, and they have slightly more than one unemployment spell each, due to the strict sampling criterion discussed above (they must have at least 52 weeks of employment before becoming unemployed). An unemployment spell contains around 0.9 meetings on average for workers aged below 30 and 1.1-1.3 meetings for workers aged above 30. This closely follows the average unemployment duration in the similar sample. The weekly meetings intensity in all four samples is around 0.04. It is also seen that there are significantly many unemployment spells with several meetings to justify analyses of the impacts of sequences of meetings.

Table 2: Descriptive statistics

\begin{tabular}{lrrrr}
\hline & $\begin{array}{c}\text { Women } \\
\text { aged 18-29 }\end{array}$ & $\begin{array}{c}\text { Men } \\
\text { aged 18-29 }\end{array}$ & $\begin{array}{c}\text { Women } \\
\text { aged 30-49 }\end{array}$ & $\begin{array}{c}\text { Men } \\
\text { aged 30-49 }\end{array}$ \\
\hline Number of persons & 9,044 & 9,049 & 12,617 & 11,795 \\
Number of unemployment spells & 9,836 & 10,202 & 13,695 & 13,225 \\
Average spell duration in weeks & 20 & 20 & 28 & 25 \\
Total number of weeks with at least 1 meeting & 9,136 & 9,142 & 18,080 & 14,520 \\
Average number of weeks with meetings per spell & 0.93 & 0.90 & 1.32 & 1.10 \\
Average number of meetings per week & 0.04 & 0.04 & 0.04 & 0.04 \\
Spells with 0 meetings & 5,991 & 6,408 & 7,023 & 7,453 \\
Spells with 1 meeting & 1,887 & 1,892 & 2,947 & 2,712 \\
Spells with 2 meetings & 800 & 741 & 1,371 & 1,247 \\
Spells with 3 meetings & 438 & 399 & 792 & 614 \\
Spells with 4 meetings or more & 720 & 762 & 1,562 & 1,199 \\
\hline
\end{tabular}

Figure 2 shows the estimated discrete-time Kaplan-Meier hazard probabilities for the first meeting in the unemployment spell, the time between the first and the second meeting, between the second and third, and third and fourth meetings. The probability of participating in the first meeting is around three percent during the first year of unemployment except around the $13^{\text {th }}$ week and around one year of unemployment, where the probability of participating in a meeting is 5 percent per week. The second, third and fourth meeting are most likely to be held during the first couple of weeks after the previous meeting, and there is also a peak around 13 weeks after the previous meeting.

In Figure 3, we plot the estimated discrete-time Kaplan-Meier hazard probabilities for the transition from unemployment into employment. Not surprisingly, the job finding rate is highest in the beginning of an unemployment spell and it continues to fall during the first year of unemployment. 
Figure 2: Kaplan-Meier hazard probabilities for transition into the first, second, third and fourth meeting (excl. CV meetings) from unemployment

(a) Women aged 18-29

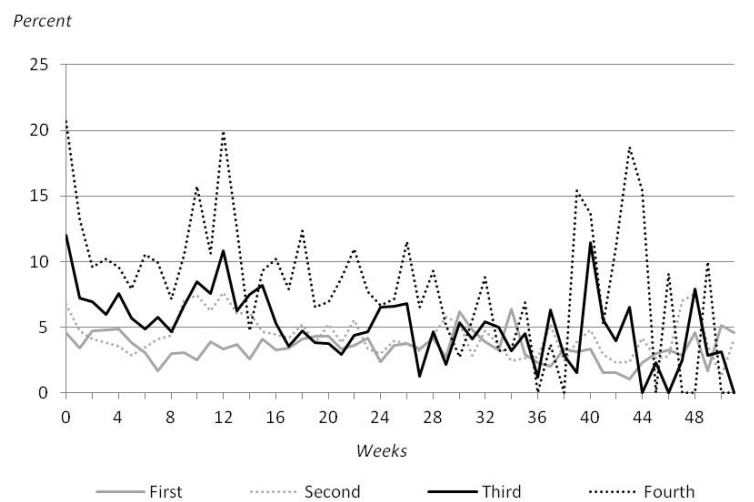

(c) Women aged 30-49

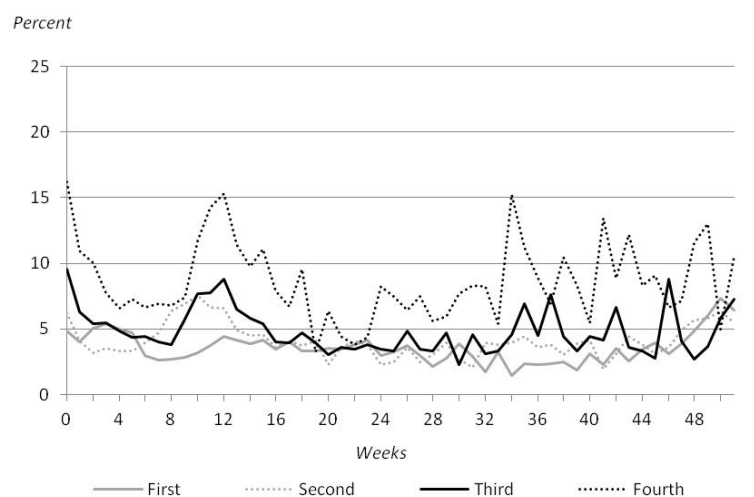

(b) Men aged 18-29

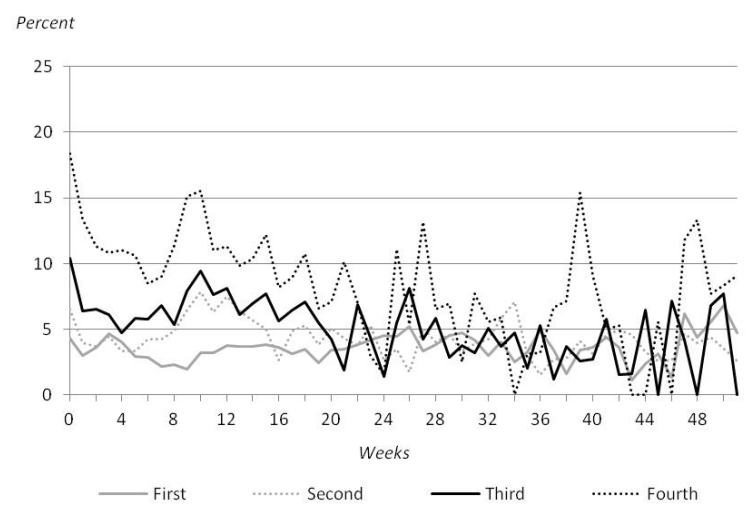

(d) Men aged 30-49

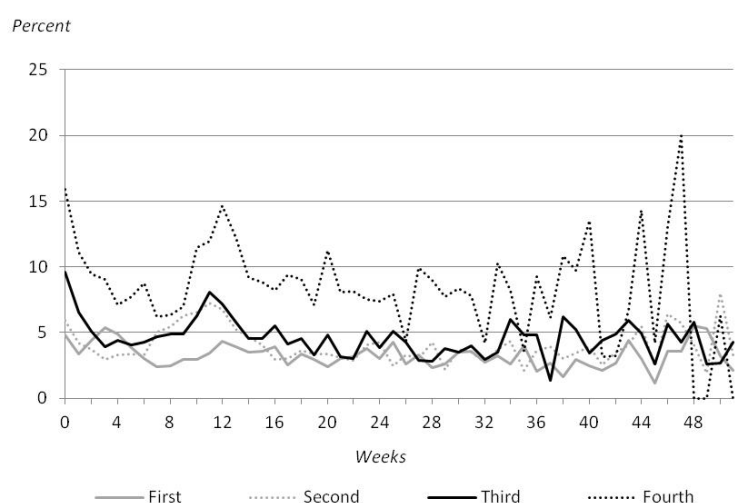

Figure 3: Kaplan-Meier hazard probabilities for transition into employment from unemployment
(a) Aged 18-29
(b) Aged 30-49
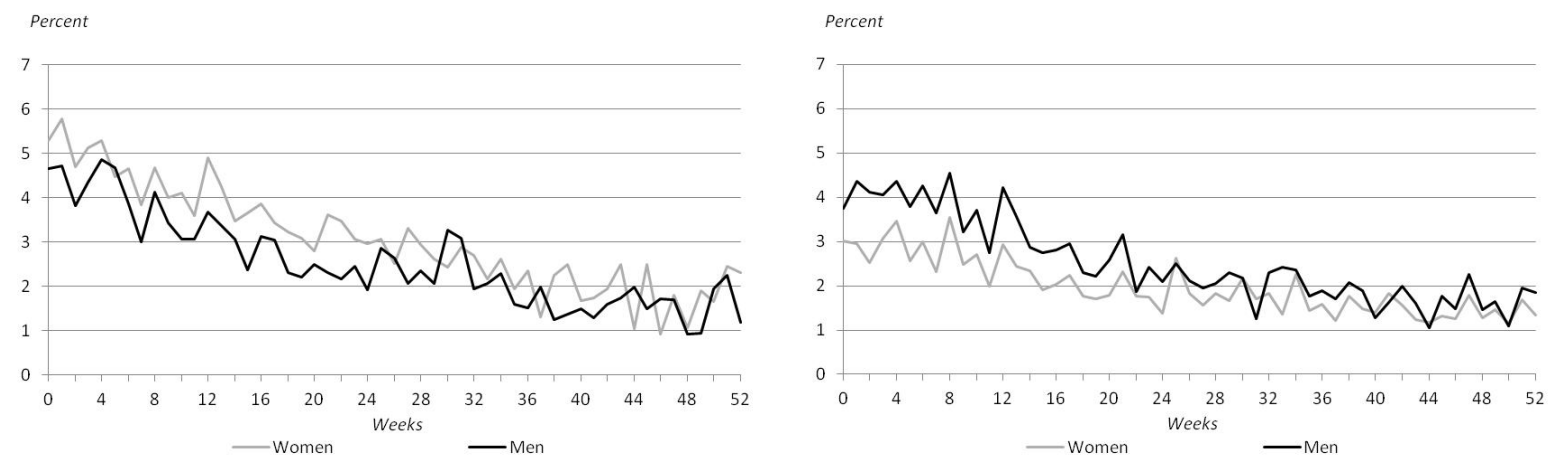


\section{$5 \quad$ Econometric model}

\subsection{Basic model specification}

The econometric analysis is based on the Timing-of-Events approach by Abbring and van den Berg (2003). Our aim is to estimate the treatment effect of meetings attended by the unemployed workers. The model is extended by allowing for sequences of meetings. In addition, we will allow for the effects of meetings to depend on their timing in the unemployment spell.

The Timing-of-Events method specifies a joint model for the transition out of unemployment and the participation rate in meetings. The time-varying treatment effect of participation in meetings is non-parametrically identified. There is no need for an exclusion restriction, since the identification result relies on random variation in the timing of the treatment, in this case in the timing of the meetings. As was shown in Figure 2, there is plenty of variation in the timing of meetings, and naturally, some of this must be random from the point of view of the individual.

Unemployed workers leave unemployment after a certain period of time. Some of them participate in a meeting at some time during the unemployment spell. The duration until the end of unemployment and until the first meeting is measured by $T_{u}$ and $T_{m}$, respectively. $T_{u}$ and $T_{m}$ are continuous non-negative random variables. The individual differences in the joint distribution of $T_{u}$ or $T_{m}$ can be characterized by the explanatory variables $X$ and $V_{u}, V_{m}$ where $X$ is observed and $V_{u}, V_{m}$ are unobserved by the econometrician. $T_{u}$ and $T_{m}$ are allowed to correlate through the observed variables, $X$, through the correlation of the unobserved variables, $V_{u}$ and $V_{m}$, and through a possible treatment effect of participating in a meeting on the exit rate from unemployment.

The exit rate from unemployment to employment is specified as:

$$
\theta_{u}\left(t \mid x(t), d(t), e(t), v_{u}\right)=\lambda_{u}(t) \cdot \varphi_{u}\left(x(t), d(t), e(t), v_{u}\right)
$$

$\lambda_{u}(t)$ is the baseline hazard, and $\varphi_{u}\left(x(t), d(t), e(t), v_{u}\right)$ is a scaling function specified as $\exp \left(x(t) \beta_{u}+d(t) \gamma_{1}+e(t) \gamma_{2, t-t_{m}}+v_{u}\right)$. Here, we consider only the first meeting held during the unemployment spell. Extensions follow below. The variables $d(t)$ and $e(t)$ are indicators for attending a meeting in week $t$, and for having attended a meeting before week $t$, respectively. The time-index on the coefficient of $e(t)$ allows the effect of the meeting to vary with time since the last meeting.

To identify the treatment effect in the Timing-of-Events approach, some assumptions are necessary. The first assumption is non-anticipation of the exact meeting date. This implies that the realization of $T_{m}$ affects the shape of the hazard of $T_{u}$ only from $T_{m}$ and onwards. The assumption rules out that private knowledge of the meeting time affects $\theta_{u}\left(t \mid x(t), d(t), e(t), v_{u}\right)$ before $T_{m}$. Hence, the individuals are allowed to know the distribution of time until a meeting but not the exact date of the meeting. This assumption is likely to be fulfilled (or at least not seriously violated) in the current analysis, because 
meeting dates are typically announced only one week in advance. The fact that the next meeting is more likely to occur at 13 weeks than at 12 weeks since the previous meeting is easily accommodated into the model specification and hence is estimated along with the other parameters. A second crucial assumption is that the hazard rates are specified as mixed proportional hazards.

The first assumption also implies that there should be some random variation in the timing of the meetings. It is highly likely to be the case, since not all meetings take place with exactly 13 weeks between them as specificed by the rules. Reasons for such variations could be quits, sickness absence, holidays, and training courses for the case workers, the workload of case workers might suddenly change due to large (or small) inflows of workers to unemployment (which could be caused by cyclilcal, seasonal, and monthly patterns e.g. unemployment spells are more likely to begin at the start of a month than during the month). In short, there are several reasons for why the exact timing of a meeeting may vary due to causes that are exogenous to the unemployed worker.

As noted in Section 2, the change in the rules of meetings intensity introduced in 2003 was gradual and coincided with a deterioration of cyclical conditions. We control for all this by including time-varying calendar-time indicators. The exogenous change in the rules, occurring at random unemployment durations for spells ongoing at the time of the policy change, adds further random variation to the timing of meetings (in a sensitivity analysis, we estimate models allowing the causal effect of meetings to depend on whether the meetings regime was the pre-2003 regime or the more recent regime).

In order to model the potential endogeneity of meetings, we must also specify a selection equation, measuring the time until the first meeting, to be estimated simultaneously with the model for exit from unemployment to employment.

$$
\theta_{m}\left(t \mid x(t), v_{m}\right)=\lambda_{m}(t) \cdot \varphi_{m}\left(x(t), v_{m}\right) .
$$

The results from the estimation of this model will be our basic specification. The baseline hazard, $\lambda(t)$, is flexibly specified as a piecewise-constant hazard, where we divide the time line into a number of intervals. For both hazards, the time line is divided into 16 intervals measured in weeks $(0-1,1$ - 2, 2-4, 4- 6, 6- 8, 8-12, 12 - 16, 16 - 22, 22 - 28, 28 - 38, 38 - 46, 46 - 52, 52 - 60, 60 - 96, 96 - 104, 104- ).

The unobserved variables, $V_{u}$ and $V_{m}$, are assumed to follow a discrete distribution with an unknown number of mass points. This allows for unrestricted correlation between $V_{u}$ and $V_{m}$, which is important because this is essentially the channels through which the model allows for selection on unobservables.

We define $C_{u}$ to be a non-censoring indicator variable, that takes the value 1 when an unemployment spell is followed by employment and 0 otherwise. The contribution to the likelihood function of one individual with $J$ unemployment spells, given observed and unobserved characteristics, is the following likelihood function: 


$$
L\left(v_{u}, v_{m}\right)=\prod_{j=1}^{J}\left(\begin{array}{c}
\theta_{m}\left(t_{m j} \mid x_{j}\left(t_{m j}\right), v_{m}\right)^{1\left[t_{m j}<t_{u j}\right]} \cdot \exp \left[-\Theta_{m}\left(t_{m j} \mid x_{j}\left(t_{m j}\right), v_{m}\right)\right] \cdot \\
\theta_{u}\left(t_{u j} \mid x_{j}\left(t_{u j}\right), d(t), e(t), v_{u}\right)^{c_{u j}} \cdot \exp \left[-\Theta_{u}\left(t_{u j} \mid x_{j}\left(t_{u j}\right), d(t), e(t), v_{u}\right)\right]
\end{array}\right) .
$$

where $\Theta(\cdot)$ denotes the integrated hazard. The model is estimated using maximum likelihood, where the individual likelihood contributions are:

$$
L=\iint L\left(v_{u}, v_{m}\right) d G\left(v_{u}, v_{m}\right)
$$

and where $G$ is the joint distribution function of the unobserved variables. If the individual experiences multiple unemployment spells in the observation window, we exploit this by assuming that the unobserved heterogeneity terms are identical across spells. This, as well as the use of time-varying explanatory variables, reduces the sensitivity of the estimates to functional form assumptions and to the mixed proportional hazards assumption (van den Berg (2001)).

\subsection{Extensions}

We now consider a couple of extensions. First, it is trivial to allow the treatment effect to vary with unemployment duration at the time of the meeting and with calender time indicators.

Second, we wish to investigate the effects of sequences meetings. This can be done by measuring the time from becoming unemployed and until the $1^{\text {st }}$ meeting, from the $1^{\text {st }}$ to the $2^{\text {nd }}$ meeting, from the $2^{\text {nd }}$ to the $3^{\text {rd }}$ meeting, etc., and modelling selection equations for the time between meetings simultaneously with the main equation, and at the same time including extra indicators for subsequent meetings in the exit rate from unemployment to employment. This model is based on

$$
\begin{aligned}
\theta_{u}\left(t \mid x(t), d_{1}(t), e_{1}(t), \ldots, d_{K}(t), e_{K}(t), v_{u}\right) & =\lambda_{u}(t) \cdot \varphi_{u}\left(x(t), d_{1}(t), e_{1}(t), \ldots, d_{K}(t), e_{K}(t), v_{u}\right), \\
\theta_{m i}\left(t \mid x(t), v_{m i}\right) & =\lambda_{m i}(t) \cdot \varphi_{m i}\left(x(t), v_{m i}\right), \quad i=1,2, \ldots, K
\end{aligned}
$$

where $K$ is the number of meetings. We will restrict the model by allowing the $K$ different selection equations to differ only via a set of indicators for the order of the meeting. The baseline hazards and the systematic unobserved determinants $v$ are taken to be the same.

\section{Results}

Table 3 shows the results obtained from estimating the Timing-of-Events model with unobserved heterogeneity with seven mass points based on the hazard specifications (1) and (2) above. This model estimates the effect of the first meeting, ignoring any subsequent 
Table 3: The effects of the first meetings between the caseworker and unemployed worker on the exit rate to employment

\begin{tabular}{lcccc}
\hline & $\begin{array}{c}\text { Women } \\
\text { aged 18-29 }\end{array}$ & $\begin{array}{c}\text { Men } \\
\text { aged 18-29 }\end{array}$ & $\begin{array}{c}\text { Women } \\
\text { aged 30-49 }\end{array}$ & $\begin{array}{c}\text { Men } \\
\text { aged 30-49 }\end{array}$ \\
\hline Week of meeting $\left[\delta_{1}\right]$ & $0.226^{* *}$ & $0.227^{* * *}$ & 0.108 & $0.256^{* * *}$ \\
& $(0.090)$ & $(0.083)$ & $(0.083)$ & $(0.071)$ \\
1-2 weeks after meeting $\left[\delta_{2}\right]$ & & $0.200^{* * *}$ & & \\
1-8 weeks after meeting $\left[\delta_{2}\right]$ & $0.217^{* * *}$ & $(0.064)$ & $0.080^{* *}$ & \\
& $(0.045)$ & & $(0.040)$ & $0.070^{* *}$ \\
1+ weeks after meeting $\left[\delta_{2}\right]$ & & & & $(0.032)$ \\
3+ weeks after meeting $\left[\delta_{2}\right]$ & & $0.069^{*}$ & & \\
9+ weeks after meeting $\left[\delta_{2}\right]$ & 0.043 & $(0.039)$ & & $0.153^{* * *}$ \\
& $(0.055)$ & & $(0.042)$ & \\
\hline
\end{tabular}

Notes: Standard errors in parentheses; ${ }^{* * *},{ }^{* *}$ and ${ }^{*}$ indicate significance at the $1 \%, 5 \%$ and $10 \%$ level, respectively.

meetings taking place. These might then, to some extent, be captured by the effect of the first meeting. Only the effects of the meetings between the unemployed and their case worker will be discussed and are shown in the table. The effects of other explanatory variables, such as socio-economic and demographic characteristics, participation in activation programs, calendar time dummies, etc., for both the hazard rates into meetings and employment from this estimation are shown in the Table A2 in the Appendix.

The model was initially estimated with a number of parameters for the post-treatment period. Subsequently, we tested the number of parameters down using LR-tests, in order to obtain tractable results.

In the week where the meeting is held, there is in three out of the four samples around 25 percent increase in the exit rate to employment. ${ }^{1}$ For women above 30 , the increase is only 11 percent, and it is not statistically significant. Subsequently, the effect tends to decline but in most cases it remains statistically significant for at least some weeks after the meeting. For women above 30, the effect becomes significantly positive, and for men above 30 the effect remains significantly positive in all subsequent weeks. On average, there are thus quite large effects of the first meetings with a case worker. At least, these effects are larger than the average treatment effects derived from many activation programs that last for weeks or months. In comparison, a meeting typically lasts 30 minutes. Hence, here is a first indication that meetings are quite a potent instrument in the toolbox of labor market policy makers.

We then proceed to estimating a model similar to the one above, where meeting effects would vary with the timing of the meeting. However, we did not find any significant variations in the effect of the first meeting, whether it was held in the first, second,

\footnotetext{
${ }^{1}$ The change is calculated by taking the exponential function of the parameter estimates and subtracting 1 .
} 
third, or a later month of unemployment. These results are therefore not reported but are available on request.

Next, we estimate the effects of sequences of meetings based on the hazard specification (3) above. In order to restrict the number of parameters, all effects are estimated with time-varying indicators for the week of the meeting, for 1-8 weeks after the meeting, and for $9+$ weeks after the meeting. When a new meeting is held, all indicators of previous meetings are set to zero. The results and the 95\%-confidence intervals of this model are shown in Figure 4, where it is assumed that meetings are held every 13 weeks. The results are, if anything, even more compelling than those for the first meeting. The peak in the exit rate at the time of the meeting continues to grow relative to the baseline, and ex post meeting effects are also increasing with the total number of meetings held in the unemployment spell (except for men below 30). This suggests that it is not only the first meeting that matters but that subsequent meetings have additional positive effects. The previous result regarding the insignificance of the timing of the meeting suggests that a further intensification of meetings would lead to higher job finding rates. This hypothesis is also supported by the empirical evidence in Pedersen et al. (2012) obtained from a social experiment.

The average effect over these 52 weeks after the first meeting range from around 55 percent for the young women to approximately 25 percent for the three other samples (these numbers are found by taking the exponential function of the coefficients reported in the figure, subtracting 1 , and calculating the average value over the 52 weeks). This suggests that the intensified use of meetings has caused a significant decline in average unemployment duration as well as a twist towards less negative duration dependence (since there are more meetings at higher durations after the 2003 reform). However, the largest potential gains would be to move the first meeting so that it takes place earlier in the unemployment spell, since that will affect most unemployed workers at a time where the absolute effect will be largest (since the exit rate is higher at shorter durations and we found no time-variation in the relative effect with respect to the timing of the first meeting).

We also estimated a model with separate effects for the pre- and post-2003 reform periods (results available upon request) and we conclude that the main results are largely unaffected. The effects of meetings after January 2003 seem to be somewhat smaller. This may be because of the business cycle being somewhat more adverse, or it may be due to declining marginal returns caused by the increased use of the instrument. A higher frequency of meetings may involve some crowding out. At the extreme, if the meetings would be held daily, the separate effect of a single meeting will tend to zero.

We may relate the empirical findings of this section to the theoretical discussion of the impacts of meetings. The peaks in the exit rates to employment around the time of meetings point to the presence of significant effects of vacancy referrals and other immediate job search assistance. In addition, the more permanent increase in job finding rates after each meeting suggest longer-run benefits of job search assistance (although 
Figure 4: The effects of sequences of the meetings between the caseworker and unemployed worker on the exit rate to employment

(a) Women aged 18-29

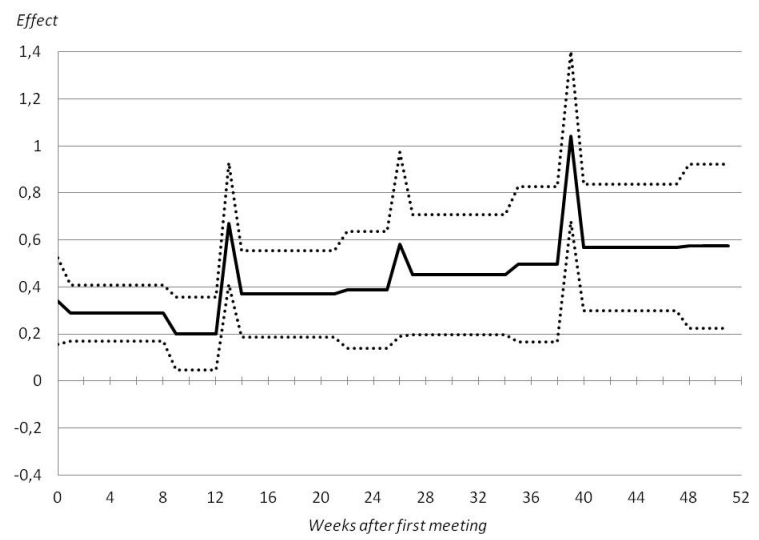

(c) Women aged 30-49

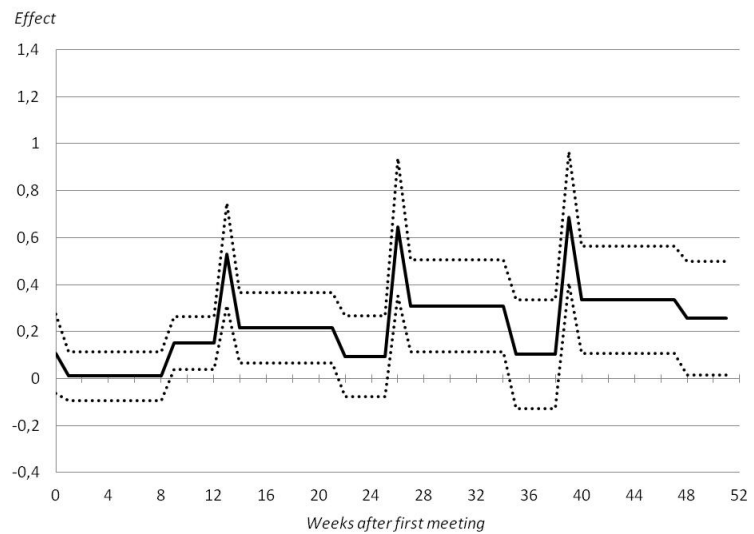

(b) Men aged 18-29

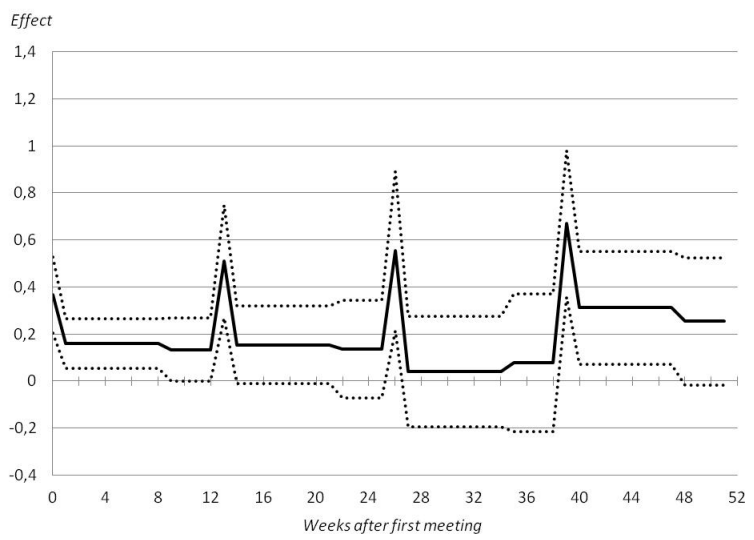

(d) Men aged 30-49

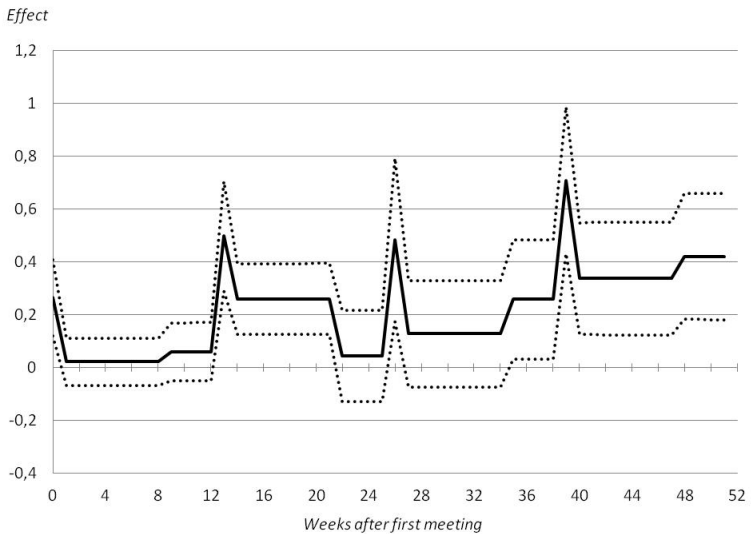

Note: The dotted lines are the $95 \%$-confidence intervals. The relative effects on the exit rates can be obtained by taking the exponential function and subtracting 1 .

here the significance is not unambiguous across groups and across time). ${ }^{2}$ Presumably, longer-run effects concern the implementation of more effective job search strategies. Perhaps monitoring is intensified after meetings as well.

\section{Conclusion}

We have investigated the effects of meetings between the unemployed and their case workers on the transition rate from unemployment to employment using detailed Danish event history data obtained from administrative registers. We find large positive effects

\footnotetext{
${ }^{2}$ Notice that our analysis allows for the identification of longer-run effects by comparing the transition rate some time after meeting number $i$ but before meeting $i+1$ to the transition rate at the same elapsed unemployment duration among those who have not had meeting $i$ yet, correcting for selectivity along the Timing-of-Events approach.
} 
of meetings, and moreover, we find that the effect tends to build up as more meetings are held. We find that the effect of the first meeting on the hazard rate does not depend on the timing of the meeting. The job finding rate increases during the week the meeting is held, and it remains positive for some weeks after the meeting. The impact of meetings tends to increase with the number of meetings held. On the whole, we find slightly larger meetings effects for women than for men.

Our results point at the importance of actual meetings between case workers and unemployed individuals, as a tool to reduce unemployment durations. Meetings effects appear to be driven by highly significant direct vacancy referral effects. In addition, we find some evidence for longer-run job search assistance (and perhaps monitoring) effects leading to more effective job search throughout the unemployment spell. The point estimates can be used to quantify the relative sizes of short-run and longer-run effects. In more elaborate models one may allow for accumulation effects of various aspects of the individual meetings history, but this would warrant larger samples than we have at our disposal. The results suggest that moving the first meeting in unemployment closer towards the moment of entry into unemployment would lead to a further reduction in unemployment duration, and that a shortening of the time intervals in between meetings might do the same. It remains an open question to what extent the meetings can be replaced by contacts through mail or over the internet without losing some of the quality of the information transfer. At the very least, showing up at meetings involves an element of monitoring that would be hard to emulate electronically.

In this paper we have not studied wage effects of meetings. This, as well as the impact of meetings on vacancy creation and on the overall functioning of the labor market could be fruitful avenues for future research. Another topic for future research might be to consider autoregressive conditional duration models (Engle and Russell (1998)). These models are used to study high-frequency financial transactions where the durations between transactions are irregular and autocorrelated. With an increasing frequency of meetings between an unemployed worker and the case worker, these models may provide a useful tool to examine interrelations between the effects of consecutive meetings. 


\section{References}

Abbring, J. H. and G. J. van den Berg (2003). The non-parametric identification of treatment effects in duration models. Econometrica 71(5), 1491-1517.

Abbring, J. H. and G. J. van den Berg (2005). Social experiments and intrumental variables with duration outcomes. Working Paper Series 2005:11, IFAU - Institute for Labour Market Policy Evaluation.

Card, D., J. Kluve, and A. Weber (2010). Active labour market policy evaluations: A meta-analysis. Economic Journal 120(548), 452-477.

Engle, R. F. and J. R. Russell (1998). Autoregressive conditional duration: A new model for irregularly spaced transaction data. Econometrica 66(5), 1127-1162.

Frederiksen, A. and N. Westergaard-Nielsen (2007). Where did they go? Modelling transitions out of jobs. Labour Economics 14(5), 811-828.

Heckman, J. J., R. J. Lalonde, and J. A. Smith (1999). The economics and econometrics of active labor market programs. In O. Ashenfelter and D. Card (Eds.), Handbook of Labor Economics, Volume 3 of Handbook of Labor Economics, Chapter 31, pp. 18652097. Elsevier.

Kluve, J. (2010). The effectiveness of european active labor market programs. Labour Economics 17(6), 904-918.

Martin, J. P. and D. Grubb (2001). What works and for whom: A review of OECD countries' experiences with active labour market policies. Swedish Economic Policy Review 8(2), 9-56.

Pedersen, J. M., M. Rosholm, and M. Svarer (2012). Experimental evidence on the effects of early meetings and activation. Manuscript in production.

The Danish Economic Council (2007). The Danish Economy, Spring 2007 (in Danish). The Danish Economic Council. Secretariat of the Danish Economic Council.

van den Berg, G. J. (1990). Nonstationarity in job search theory. Review of Economic Studies 57(2), 255-77.

van den Berg, G. J. (1994). The effects of changes of the job offer arrival rate on the duration of unemployment. Journal of Labor Economics 12(3), 478-98.

van den Berg, G. J. (2001). Duration models: specification, identification and multiple durations. In J. Heckman and E. Leamer (Eds.), Handbook of Econometrics, Volume 5 of Handbook of Econometrics, Chapter 55, pp. 3381-3460. Elsevier. 


\section{A Appendix}

Table A.1: Sample means

\begin{tabular}{|c|c|c|c|c|}
\hline & $\begin{array}{l}\text { Women } \\
\text { aged 18-29 }\end{array}$ & $\begin{array}{l}\text { Men } \\
\text { aged 18-29 }\end{array}$ & $\begin{array}{l}\text { Women } \\
\text { aged 30-49 }\end{array}$ & $\begin{array}{c}\text { Men } \\
\text { aged 30-49 }\end{array}$ \\
\hline Children age $0-2$ & 0.23 & 0.10 & 0.18 & 0.14 \\
\hline Children age $3-6$ & 0.15 & 0.04 & 0.27 & 0.17 \\
\hline Children age $7-17$ & 0.04 & 0.01 & 0.48 & 0.27 \\
\hline Children age $0-2$ & 0.23 & 0.10 & 0.18 & 0.14 \\
\hline Children age $3-6$ & 0.15 & 0.04 & 0.27 & 0.17 \\
\hline Children age $7-17$ & 0.04 & 0.01 & 0.48 & 0.27 \\
\hline Age $18-24$ & 0.64 & 0.57 & & \\
\hline Age 25-29 (reference category) & 0.36 & 0.43 & & \\
\hline Age 30-34 (reference category) & & & 0.31 & 0.28 \\
\hline Age 35-39 & & & 0.28 & 0.28 \\
\hline Age $40-44$ & & & 0.22 & 0.22 \\
\hline Age 45-49 & & & 0.19 & 0.22 \\
\hline Married & 0.21 & 0.11 & 0.57 & 0.44 \\
\hline Single (reference category) & 0.79 & 0.89 & 0.43 & 0.56 \\
\hline Primary school & 0.29 & 0.37 & 0.30 & 0.31 \\
\hline High school & 0.23 & 0.17 & 0.07 & 0.07 \\
\hline Vocational education (reference category) & 0.03 & 0.03 & 0.06 & 0.40 \\
\hline Short-term tertiary education (1-2 years ) & 0.03 & 0.06 & 0.06 & 0.06 \\
\hline Long- term tertiary education (3-6 years) & 0.14 & 0.08 & 0.18 & 0.15 \\
\hline Immigrant from OECD countries & 0.03 & 0.04 & 0.03 & 0.05 \\
\hline Immigrant from non-OECD countries & 0.03 & 0.04 & 0.03 & 0.05 \\
\hline Danes (reference category) & 0.93 & 0.92 & 0.94 & 0.90 \\
\hline Living in a bigger city & 0.22 & 0.25 & 0.15 & 0.19 \\
\hline Living at the country & 0.61 & 0.59 & 0.73 & 0.66 \\
\hline Living in Copenhagen (reference category) & 0.18 & 0.16 & 0.12 & 0.15 \\
\hline Years of work experiences & 3.47 & 4.00 & 11.70 & 13.15 \\
\hline Weeks of sickness benefit last year & 1.89 & 1.52 & 3.80 & 3.11 \\
\hline Weeks of sickness benefit two years ago & 0.68 & 0.80 & 1.39 & 1.26 \\
\hline Weeks of public income transfers last year & 9.00 & 3.46 & 10.05 & 5.75 \\
\hline Weeks of public income transfers 2 years ago & 7.91 & 5.31 & 10.37 & 7.31 \\
\hline $\begin{array}{l}\text { Weeks of public income transfers } 3 \text { and } 4 \\
\text { years ago }\end{array}$ & 15.84 & 11.98 & 27.42 & 19.32 \\
\hline UI fund construction & 0.02 & 0.10 & 0.02 & 0.07 \\
\hline UI fund metal & 0.00 & 0.12 & 0.00 & 0.08 \\
\hline $\begin{array}{l}\text { UI fund manufacturing, restaurant } \\
\text { (reference category) }\end{array}$ & 0.15 & 0.26 & 0.19 & 0.28 \\
\hline UI fund production & 0.02 & 0.03 & 0.02 & 0.02 \\
\hline UI fund technicians & 0.03 & 0.06 & 0.05 & 0.08 \\
\hline UI fund trade & 0.29 & 0.13 & 0.22 & 0.07 \\
\hline UI fund services & 0.24 & 0.08 & 0.28 & 0.12 \\
\hline UI fund academics & 0.15 & 0.13 & 0.09 & 0.11 \\
\hline UI fund self-employed & 0.01 & 0.02 & 0.04 & 0.06 \\
\hline Other UI fund & 0.09 & 0.07 & 0.10 & 0.09 \\
\hline Union member & 0.72 & 0.72 & 0.80 & 0.79 \\
\hline Non-union member (reference category) & 0.28 & 0.28 & 0.20 & 0.21 \\
\hline Unemployment rate for UI fund & 6.26 & 6.75 & 6.31 & 6.76 \\
\hline
\end{tabular}


Table A.1 - Continued from previous page

\begin{tabular}{lcccc}
\hline & $\begin{array}{c}\text { Women } \\
\text { aged 18-29 }\end{array}$ & $\begin{array}{c}\text { Men } \\
\text { aged 18-29 }\end{array}$ & $\begin{array}{c}\text { Women } \\
\text { aged 30-49 }\end{array}$ & $\begin{array}{c}\text { Men } \\
\text { aged 30-49 }\end{array}$ \\
\hline First quarter (reference category) & 0.28 & 0.29 & 0.29 & 0.30 \\
Second quarter & 0.20 & 0.19 & 0.23 & 0.22 \\
Third quarter & 0.31 & 0.27 & 0.27 & 0.23 \\
Fourth quarter & 0.21 & 0.24 & 0.21 & 0.25 \\
Year 2001 & 0.20 & 0.21 & 0.21 & 0.21 \\
Year 2002 & 0.19 & 0.20 & 0.21 & 0.22 \\
Year 2003 & 0.27 & 0.22 & 0.23 & 0.27 \\
Year 2004 & 0.24 & 0.26 & 0.26 & 0.21 \\
Year 2005 (reference category) & 0.10 & 0.10 & 0.09 & 0.08 \\
\hline
\end{tabular}


Table A.2: Full estimation results

\begin{tabular}{|c|c|c|c|c|}
\hline & $\begin{array}{l}\text { Women } \\
\text { aged } 18-29\end{array}$ & $\begin{array}{c}\text { Men } \\
\text { aged 18-29 }\end{array}$ & $\begin{array}{l}\text { Women } \\
\text { aged } 30-49\end{array}$ & $\begin{array}{c}\text { Men } \\
\text { aged 30-49 }\end{array}$ \\
\hline \multicolumn{5}{|l|}{$\begin{array}{l}\text { Hazard rate into employment } \\
\text { Baseline in weeks }\end{array}$} \\
\hline $0-1$ & $\begin{array}{c}-3.649 \\
(6.687)\end{array}$ & $\begin{array}{c}-3.748 \\
(356.2)\end{array}$ & $\begin{array}{r}-3.846 \\
(6.773)\end{array}$ & $\begin{array}{r}-3.276 \\
(22.85)\end{array}$ \\
\hline $1-2$ & $\begin{array}{c}-3.621 \\
(6.690)\end{array}$ & $\begin{array}{r}-3.650 \\
(356.2)\end{array}$ & $\begin{array}{c}-3.861 \\
(6.770)\end{array}$ & $\begin{array}{c}-3.118 \\
(22.86)\end{array}$ \\
\hline $2-4$ & $\begin{array}{c}-3.748 \\
(6.689)\end{array}$ & $\begin{array}{c}-3.804 \\
(356.2)\end{array}$ & $\begin{array}{r}-3.913 \\
(6.772)\end{array}$ & $\begin{array}{r}-3.163 \\
(22.85)\end{array}$ \\
\hline $4-5$ & $\begin{array}{c}-3.578 \\
(6.688)\end{array}$ & $\begin{array}{c}-3.785 \\
(356.2)\end{array}$ & $\begin{array}{c}-3.832 \\
(6.772)\end{array}$ & $\begin{array}{r}-3.143 \\
(22.86)\end{array}$ \\
\hline $6-8$ & $\begin{array}{r}-3.885 \\
(6.687)\end{array}$ & $\begin{array}{c}-3.899 \\
(356.2)\end{array}$ & $\begin{array}{c}-3.954 \\
(6.770)\end{array}$ & $\begin{array}{r}-3.149 \\
(22.86)\end{array}$ \\
\hline $8-12$ & $\begin{array}{c}-3.851 \\
(6.685)\end{array}$ & $\begin{array}{c}-3.904 \\
(356.2)\end{array}$ & $\begin{array}{r}-3.929 \\
(6.770)\end{array}$ & $\begin{array}{r}-3.216 \\
(22.85)\end{array}$ \\
\hline $12-16$ & $\begin{array}{c}-3.911 \\
(6.689)\end{array}$ & $\begin{array}{c}-3.890 \\
(356.2)\end{array}$ & $\begin{array}{c}-4.048 \\
(6.769)\end{array}$ & $\begin{array}{c}-3.251 \\
(22.85)\end{array}$ \\
\hline $16-22$ & $\begin{array}{c}-4.075 \\
(6.688)\end{array}$ & $\begin{array}{r}-4.040 \\
(356.2)\end{array}$ & $\begin{array}{c}-4.249 \\
(6.769)\end{array}$ & $\begin{array}{c}-3.453 \\
(22.86)\end{array}$ \\
\hline $22-28$ & $\begin{array}{c}-4.125 \\
(6.687)\end{array}$ & $\begin{array}{c}-4.071 \\
(356.2)\end{array}$ & $\begin{array}{c}-4.337 \\
(6.774)\end{array}$ & $\begin{array}{c}-3.634 \\
(22.86)\end{array}$ \\
\hline $28-38$ & $\begin{array}{c}-4.064 \\
(6.686)\end{array}$ & $\begin{array}{c}-4.222 \\
(356.2)\end{array}$ & $\begin{array}{c}-4.391 \\
(6.770)\end{array}$ & $\begin{array}{c}-3.671 \\
(22.86)\end{array}$ \\
\hline $38-46$ & $\begin{array}{c}-4.367 \\
(6.688)\end{array}$ & $\begin{array}{c}-4.343 \\
(356.2)\end{array}$ & $\begin{array}{c}-4.521 \\
(6.767)\end{array}$ & $\begin{array}{c}-3.835 \\
(22.86)\end{array}$ \\
\hline $46-52$ & $\begin{array}{c}-4.275 \\
(6.686)\end{array}$ & $\begin{array}{c}-4.548 \\
(356.2)\end{array}$ & $\begin{array}{r}-4.527 \\
(6.772)\end{array}$ & $\begin{array}{r}-3.837 \\
(22.86)\end{array}$ \\
\hline $52-60$ & $\begin{array}{c}-4.444 \\
(6.684)\end{array}$ & $\begin{array}{c}-4.35 \\
(356.2)\end{array}$ & $\begin{array}{c}-4.684 \\
(6.772)\end{array}$ & $\begin{array}{r}-3.988 \\
(22.85)\end{array}$ \\
\hline $60-96$ & $\begin{array}{c}-4.387 \\
(6.687)\end{array}$ & $\begin{array}{c}-4.316 \\
(356.2)\end{array}$ & $\begin{array}{r}-4.790 \\
(6.772)\end{array}$ & $\begin{array}{c}-3.981 \\
(22.86)\end{array}$ \\
\hline $96-104$ & $\begin{array}{r}-4.478 \\
(6.687)\end{array}$ & $\begin{array}{c}-4.884 \\
(356.2)\end{array}$ & $\begin{array}{c}-4.974 \\
(6.761)\end{array}$ & $\begin{array}{c}-4.208 \\
(22.86)\end{array}$ \\
\hline $104-$ & $\begin{array}{r}-4.536 \\
(6.691)\end{array}$ & $\begin{array}{c}-4.675 \\
(356.2)\end{array}$ & $\begin{array}{c}-4.879 \\
(6.774)\end{array}$ & $\begin{array}{c}-4.447 \\
(22.86)\end{array}$ \\
\hline Variables & & & & \\
\hline Children age $0-2$ & $\begin{array}{c}-0.022 \\
(0.050)\end{array}$ & $\begin{array}{c}0.092^{*} \\
(0.048)\end{array}$ & $\begin{array}{r}-0.026 \\
(0.040)\end{array}$ & $\begin{array}{c}0.054^{*} \\
(0.032)\end{array}$ \\
\hline Children age $3-6$ & $\begin{array}{r}-0.113^{*} \\
(0.058)\end{array}$ & $\begin{array}{c}-0.005 \\
(0.071)\end{array}$ & $\begin{array}{c}0.016 \\
(0.030)\end{array}$ & $\begin{array}{l}0.099^{* * *} \\
(0.030)\end{array}$ \\
\hline Children age $7-17$ & $\begin{array}{c}-0.223^{* *} \\
(0.101)\end{array}$ & $\begin{array}{c}-0.019 \\
(0.109)\end{array}$ & $\begin{array}{c}0.007 \\
(0.026)\end{array}$ & $\begin{array}{l}0.167^{* * *} \\
(0.027)\end{array}$ \\
\hline Age $18-24$ & $\begin{array}{l}0.179^{* * *} \\
(0.037)\end{array}$ & $\begin{array}{l}0.273^{* * *} \\
(0.035)\end{array}$ & & \\
\hline Age 35-39 & & & $\begin{array}{c}-0.100^{* * *} \\
(0.034)\end{array}$ & $\begin{array}{c}-0.194^{* * *} \\
(0.031)\end{array}$ \\
\hline Age $40-44$ & & & $\begin{array}{c}-0.134^{* * *} \\
(0.040)\end{array}$ & $\begin{array}{c}-0.296^{* * *} \\
(0.035)\end{array}$ \\
\hline Age $45-49$ & & & $\begin{array}{c}-0.264^{* * *} \\
(0.045)\end{array}$ & $\begin{array}{c}-0.470^{* * *} \\
(0.039)\end{array}$ \\
\hline Married & $\begin{array}{c}-0.116^{* * *} \\
(0.044)\end{array}$ & $\begin{array}{c}-0.083 \\
(0.051)\end{array}$ & $\begin{array}{l}0.090^{* * *} \\
(0.026)\end{array}$ & $\begin{array}{l}0.125^{* * *} \\
(0.026)\end{array}$ \\
\hline Primary school & $\begin{array}{c}-0.313^{* * *} \\
(0.043)\end{array}$ & $\begin{array}{c}-0.253^{* * *} \\
(0.034)\end{array}$ & $\begin{array}{c}-0.129^{* * *} \\
(0.032)\end{array}$ & $\begin{array}{c}-0.182^{* * *} \\
(0.029)\end{array}$ \\
\hline High school & $\begin{array}{l}0.153^{* * *} \\
(0.043)\end{array}$ & $\begin{array}{c}-0.033 \\
(0.050)\end{array}$ & $\begin{array}{c}-0.015 \\
(0.049)\end{array}$ & $\begin{array}{c}-0.228^{* * *} \\
(0.055)\end{array}$ \\
\hline Short-term tertiary education (1-2 years ) & $\begin{array}{c}-0.013 \\
(0.093)\end{array}$ & $\begin{array}{c}0.059 \\
(0.081)\end{array}$ & $\begin{array}{c}-0.053 \\
(0.055)\end{array}$ & $\begin{array}{c}-0.052 \\
(0.050)\end{array}$ \\
\hline Long- term tertiary education (3-6 years) & $\begin{array}{l}0.186^{* * *} \\
(0.057)\end{array}$ & $\begin{array}{c}-0.024 \\
(0.070)\end{array}$ & $\begin{array}{l}0.167^{* * *} \\
(0.038)\end{array}$ & $\begin{array}{r}-0.019 \\
(0.046)\end{array}$ \\
\hline
\end{tabular}


Table A.2 - Continued from previous page

\begin{tabular}{|c|c|c|c|c|}
\hline & $\begin{array}{c}\text { Women } \\
\text { aged 18-29 }\end{array}$ & $\begin{array}{c}\text { Men } \\
\text { aged 18-29 }\end{array}$ & $\begin{array}{c}\text { Women } \\
\text { aged 30-49 }\end{array}$ & $\begin{array}{c}\text { Men } \\
\text { aged 30-49 }\end{array}$ \\
\hline Immigrant from OECD countries & $\begin{array}{c}-0.079 \\
(0.094)\end{array}$ & $\begin{array}{c}-0.187^{* *} \\
(0.089)\end{array}$ & $\begin{array}{c}-0.129^{*} \\
(0.076)\end{array}$ & $\begin{array}{c}-0.193^{* * *} \\
(0.062)\end{array}$ \\
\hline Immigrant from non-OECD countries & $\begin{array}{c}-0.498^{* * *} \\
(0.128)\end{array}$ & $\begin{array}{c}-0.606^{* * *} \\
(0.102)\end{array}$ & $\begin{array}{c}-0.264^{* * *} \\
(0.088)\end{array}$ & $\begin{array}{c}-0.438^{* * *} \\
(0.079)\end{array}$ \\
\hline Living in a bigger city & $\begin{array}{c}0.023 \\
(0.044)\end{array}$ & $\begin{array}{l}0.091^{* *} \\
(0.043)\end{array}$ & $\begin{array}{c}-0.013 \\
(0.048)\end{array}$ & $\begin{array}{c}0.017 \\
(0.042)\end{array}$ \\
\hline Living at the country & $\begin{array}{c}-0.022 \\
(0.040)\end{array}$ & $\begin{array}{l}0.198^{* * *} \\
(0.040)\end{array}$ & $\begin{array}{l}0.091^{* *} \\
(0.040)\end{array}$ & $\begin{array}{l}0.185^{* * *} \\
(0.035)\end{array}$ \\
\hline Years of work experiences & $\begin{array}{l}0.687^{* * *} \\
(0.145)\end{array}$ & $\begin{array}{l}1.059^{* * *} \\
(0.127)\end{array}$ & $\begin{array}{l}0.236^{* * *} \\
(0.067)\end{array}$ & $\begin{array}{l}0.246^{* * *} \\
(0.061)\end{array}$ \\
\hline Years of work experiences ${ }^{2}$ & $\begin{array}{c}-4.180^{* * *} \\
(1.156)\end{array}$ & $\begin{array}{c}-4.665^{* * *} \\
(0.857)\end{array}$ & $\begin{array}{c}-0.518^{* *} \\
(0.219)\end{array}$ & $\begin{array}{c}-0.301 \\
(0.185)\end{array}$ \\
\hline Weeks of sickness benefit last year & $\begin{array}{c}-1.043^{* * *} \\
(0.181)\end{array}$ & $\begin{array}{c}-0.523^{* * *} \\
(0.189)\end{array}$ & $\begin{array}{c}-0.676^{* * *} \\
(0.095)\end{array}$ & $\begin{array}{c}-0.993^{* * *} \\
(0.119)\end{array}$ \\
\hline Weeks of sickness benefit two years ago & $\begin{array}{c}-0.730^{* *} \\
(0.337)\end{array}$ & $\begin{array}{c}-0.356 \\
(0.237)\end{array}$ & $\begin{array}{r}-0.272^{*} \\
(0.152)\end{array}$ & $\begin{array}{c}-0.147 \\
(0.171)\end{array}$ \\
\hline Weeks of public inc. transfers last year & $\begin{array}{c}-0.231^{* * *} \\
(0.066)\end{array}$ & $\begin{array}{r}-0.218^{*} \\
(0.117)\end{array}$ & $\begin{array}{c}-0.142^{* * *} \\
(0.053)\end{array}$ & $\begin{array}{c}-0.014 \\
(0.079)\end{array}$ \\
\hline Weeks of public inc. transf. 2 years ago & $\begin{array}{c}-0.327^{* * *} \\
(0.075)\end{array}$ & $\begin{array}{c}-0.203^{* *} \\
(0.086)\end{array}$ & $\begin{array}{l}-0.140^{* * *} \\
(0.052)\end{array}$ & $\begin{array}{c}-0.102 \\
(0.064)\end{array}$ \\
\hline Weeks of pub. inc. transf. $3 \& 4$ years ago & $\begin{array}{c}-0.462^{* * *} \\
(0.083)\end{array}$ & $\begin{array}{c}-0.828^{* * *} \\
(0.086)\end{array}$ & $\begin{array}{c}-0.328^{* * *} \\
(0.046)\end{array}$ & $\begin{array}{c}-0.685^{* * *} \\
(0.059)\end{array}$ \\
\hline UI fund construction & $\begin{array}{l}0.204^{* * *} \\
(0.035)\end{array}$ & $\begin{array}{l}0.095^{* * *} \\
(0.035)\end{array}$ & $\begin{array}{l}0.081^{* *} \\
(0.033)\end{array}$ & $\begin{array}{c}0.027 \\
(0.034)\end{array}$ \\
\hline UI fund metal & $\begin{array}{c}0.177 \\
(0.154)\end{array}$ & $\begin{array}{l}0.391^{* * *} \\
(0.079)\end{array}$ & $\begin{array}{c}0.222^{*} \\
(0.119)\end{array}$ & $\begin{array}{l}0.277^{* * *} \\
(0.072)\end{array}$ \\
\hline UI fund production & $\begin{array}{c}-0.169 \\
(0.286)\end{array}$ & $\begin{array}{c}0.064 \\
(0.086)\end{array}$ & $\begin{array}{c}0.059 \\
(0.183)\end{array}$ & $\begin{array}{c}-0.120 \\
(0.077)\end{array}$ \\
\hline UI fund technicians & $\begin{array}{c}0.041 \\
(0.131)\end{array}$ & $\begin{array}{c}-0.098 \\
(0.099)\end{array}$ & $\begin{array}{c}0.137 \\
(0.108)\end{array}$ & $\begin{array}{c}-0.185^{* *} \\
(0.092)\end{array}$ \\
\hline UI fund trade & $\begin{array}{c}-0.153 \\
(0.152)\end{array}$ & $\begin{array}{r}-0.210^{*} \\
(0.118)\end{array}$ & $\begin{array}{c}0.019 \\
(0.118)\end{array}$ & $\begin{array}{c}-0.221^{* *} \\
(0.088)\end{array}$ \\
\hline UI fund services & $\begin{array}{c}-0.059 \\
(0.085)\end{array}$ & $\begin{array}{c}-0.223^{* * *} \\
(0.072)\end{array}$ & $\begin{array}{c}-0.027 \\
(0.071)\end{array}$ & $\begin{array}{l}-0.501^{* * *} \\
(0.071)\end{array}$ \\
\hline UI fund academics & $\begin{array}{l}0.417^{* * *} \\
(0.138)\end{array}$ & $\begin{array}{l}0.220^{* *} \\
(0.112)\end{array}$ & $\begin{array}{c}0.253^{* *} \\
(0.111)\end{array}$ & $\begin{array}{c}-0.197^{* *} \\
(0.092)\end{array}$ \\
\hline UI fund self-employed & $\begin{array}{c}-0.173 \\
(0.114)\end{array}$ & $\begin{array}{l}0.059 \\
(0.095)\end{array}$ & $\begin{array}{c}-0.052 \\
(0.094)\end{array}$ & $\begin{array}{c}-0.359^{* * *} \\
(0.082)\end{array}$ \\
\hline Other UI fund & $\begin{array}{c}0.072 \\
(0.155)\end{array}$ & $\begin{array}{c}0.155 \\
(0.122)\end{array}$ & $\begin{array}{c}0.203 \\
(0.124)\end{array}$ & $\begin{array}{c}-0.221^{* *} \\
(0.102)\end{array}$ \\
\hline Union member & $\begin{array}{c}0.019 \\
(0.154)\end{array}$ & $\begin{array}{c}-0.151 \\
(0.112)\end{array}$ & $\begin{array}{c}0.009 \\
(0.086)\end{array}$ & $\begin{array}{l}-0.394^{* * *} \\
(0.067)\end{array}$ \\
\hline Unemployment rate for UI fund & $\begin{array}{c}-0.072 \\
(0.047)\end{array}$ & $\begin{array}{c}-0.059 \\
(0.050)\end{array}$ & $\begin{array}{l}-0.078^{* *} \\
(0.039)\end{array}$ & $\begin{array}{l}-0.120^{* * *} \\
(0.041)\end{array}$ \\
\hline Second quarter & $\begin{array}{l}0.048 \\
(0.037)\end{array}$ & $\begin{array}{l}-0.098^{* * *} \\
(0.037)\end{array}$ & $\begin{array}{l}-0.130^{* * *} \\
(0.033)\end{array}$ & $\begin{array}{l}-0.179^{* * *} \\
(0.032)\end{array}$ \\
\hline Third quarter & $\begin{array}{r}-0.075^{*} \\
(0.042)\end{array}$ & $\begin{array}{r}-0.061^{*} \\
(0.035)\end{array}$ & $\begin{array}{r}-0.059^{*} \\
(0.035)\end{array}$ & $\begin{array}{l}-0.151^{* * *} \\
(0.030)\end{array}$ \\
\hline Fourth quarter & $\begin{array}{c}0.592 \\
(2.235)\end{array}$ & $\begin{array}{c}2.351 \\
(1.749)\end{array}$ & $\begin{array}{c}0.004 \\
(0.018)\end{array}$ & $\begin{array}{r}-0.296 \\
(1.456)\end{array}$ \\
\hline Year 2001 & $\begin{array}{l}0.342^{* * *} \\
(0.062)\end{array}$ & $\begin{array}{l}0.260^{* * *} \\
(0.059)\end{array}$ & $\begin{array}{l}0.348^{* * *} \\
(0.054)\end{array}$ & $\begin{array}{l}0.188^{* * *} \\
(0.050)\end{array}$ \\
\hline Year 2002 & $\begin{array}{l}0.260^{* * *} \\
(0.063)\end{array}$ & $\begin{array}{r}0.112^{*} \\
(0.060)\end{array}$ & $\begin{array}{l}0.200^{* * *} \\
(0.056)\end{array}$ & $\begin{array}{c}0.067 \\
(0.050)\end{array}$ \\
\hline Year 2003 & $\begin{array}{l}0.203^{* * *} \\
(0.058)\end{array}$ & $\begin{array}{l}0.133^{* *} \\
(0.056)\end{array}$ & $\begin{array}{l}0.239^{* * *} \\
(0.053)\end{array}$ & $\begin{array}{c}0.018 \\
(0.048)\end{array}$ \\
\hline Year 2004 & $\begin{array}{l}0.191^{* * *} \\
(0.059)\end{array}$ & $\begin{array}{c}0.135^{* *} \\
(0.057)\end{array}$ & $\begin{array}{l}0.265^{* * *} \\
(0.052)\end{array}$ & $\begin{array}{c}0.084^{*} \\
(0.049)\end{array}$ \\
\hline $\begin{array}{l}\text { Locking-in effect for ALMP variables } \\
\text { Private sector employment subsidy }\end{array}$ & $2.315^{* * *}$ & 3.626 & $2.384^{* * *}$ & $2.385^{* * *}$ \\
\hline
\end{tabular}


Table A.2 - Continued from previous page

\begin{tabular}{|c|c|c|c|c|}
\hline & $\begin{array}{c}\text { Women } \\
\text { aged 18-29 }\end{array}$ & $\begin{array}{c}\text { Men } \\
\text { aged 18-29 }\end{array}$ & $\begin{array}{c}\text { Women } \\
\text { aged 30-49 }\end{array}$ & $\begin{array}{c}\text { Men } \\
\text { aged 30-49 }\end{array}$ \\
\hline \multirow{3}{*}{ Public sector employment subsidy } & $(0.279)$ & $(3.754)$ & $(0.287)$ & $(0.184)$ \\
\hline & $-0.582^{* * *}$ & $-0.396^{* *}$ & $-0.469^{* * *}$ & $-0.392^{* *}$ \\
\hline & $(0.150)$ & $(0.154)$ & $(0.127)$ & $(0.158)$ \\
\hline \multirow[t]{2}{*}{ Education/training } & $-1.157^{* * *}$ & $-0.896^{* * *}$ & $-1.018^{* * *}$ & $-0.651^{* * *}$ \\
\hline & $(0.130)$ & $(0.101)$ & $(0.089)$ & $(0.097)$ \\
\hline \multirow[t]{2}{*}{ Guidance programmes } & -0.060 & -0.040 & $0.214^{* *}$ & 0.140 \\
\hline & $(0.109)$ & $(0.111)$ & $(0.107)$ & $(0.093)$ \\
\hline \multirow[t]{2}{*}{ Other programmes } & $-0.674^{* *}$ & $-0.804^{* *}$ & -0.784 & $-1.116^{* *}$ \\
\hline & $(0.306)$ & $(0.313)$ & $(0.750)$ & $(0.552)$ \\
\hline \multicolumn{5}{|l|}{ Post effect for ALMP variables } \\
\hline \multirow[t]{2}{*}{ Private sector employment subsidy } & $2.730^{* * *}$ & 3.915 & $2.642^{* * *}$ & $2.874^{* * *}$ \\
\hline & $(0.447)$ & $(3.762)$ & $(0.404)$ & $(0.286)$ \\
\hline \multirow[t]{2}{*}{ Public sector employment subsidy } & $-2.660^{* * *}$ & -3.954 & $-2.391^{* * *}$ & $-2.598^{* * *}$ \\
\hline & $(0.314)$ & $(3.742)$ & $(0.307)$ & $(0.209)$ \\
\hline \multirow[t]{2}{*}{ Education/traininge } & $-0.404^{* * *}$ & $-0.262^{* * *}$ & -0.095 & -0.066 \\
\hline & $(0.092)$ & $(0.078)$ & $(0.062)$ & $(0.062)$ \\
\hline \multirow[t]{2}{*}{ Guidance programmes } & $-0.279^{* * *}$ & $-0.195^{* *}$ & $-0.126^{*}$ & $-0.225^{* * *}$ \\
\hline & $(0.088)$ & $(0.088)$ & $(0.073)$ & $(0.075)$ \\
\hline \multirow[t]{2}{*}{ Other programmes } & -0.479 & -0.573 & -2.282 & -0.435 \\
\hline & $(0.403)$ & $(0.410)$ & $(10.01)$ & $(0.422)$ \\
\hline \multicolumn{5}{|l|}{ Meetings variables } \\
\hline \multirow[t]{2}{*}{ week 0} & $0.226^{* *}$ & $0.227^{* * *}$ & 0.108 & $0.256^{* * *}$ \\
\hline & $(0.090)$ & $(0.083)^{*}$ & $(0.083)$ & $(0.071)$ \\
\hline week 1-2 & & $0.200^{* * *}$ & & \\
\hline \multirow{2}{*}{ week 1-8 } & $0.217^{* * *}$ & $(0.004)$ & $0.080^{* *}$ & \\
\hline & $(0.045)$ & & $(0.040)$ & \\
\hline \multirow{2}{*}{\multicolumn{2}{|c|}{ week $1+$}} & & & $0.070^{* *}$ \\
\hline & & & & $(0.032)$ \\
\hline \multirow{2}{*}{\multicolumn{2}{|c|}{ week $3+$}} & $0.069^{*}$ & & \\
\hline & & $(0.039)$ & & \\
\hline \multirow[t]{2}{*}{ week $9+$} & 0.043 & & $0.153^{* * *}$ & \\
\hline & $(0.055)$ & & $(0.042)$ & \\
\hline $\begin{array}{l}\text { Hazard rate into meetings } \\
\text { Baseline in weeks }\end{array}$ & & & & \\
\hline $0-1$ & $-3.489^{* *}$ & -3.517 & -3.194 & -3.329 \\
\hline & $(1.688)$ & $(312.2)$ & $(25.51)$ & $(40.83)$ \\
\hline $1-2$ & $-3.201^{*}$ & -3.402 & -2.996 & -3.126 \\
\hline & (1.689) & $(312.2)$ & $(25.51)$ & $(40.84)$ \\
\hline $2-4$ & $-3.166^{*}$ & -3.151 & -2.942 & -2.955 \\
\hline & (1.687) & $(312.2)$ & $(25.51)$ & $(40.84)$ \\
\hline $4-6$ & $-3.383^{* *}$ & -3.387 & -3.091 & -3.148 \\
\hline & $(1.688)$ & $(312.2)$ & $(25.51)$ & $(40.84)$ \\
\hline $6-8$ & $-3.627^{* *}$ & -3.525 & -3.428 & -3.383 \\
\hline & $(1.686)$ & $(312.2)$ & $(25.51)$ & $(40.84)$ \\
\hline $8-12$ & $-3.152^{*}$ & -2.977 & -2.716 & -2.840 \\
\hline & $(1.684)$ & $(312.2)$ & $(25.51)$ & $(40.84)$ \\
\hline $12-16$ & -2.726 & -2.749 & -2.481 & -2.539 \\
\hline & $(1.686)$ & $(312.2)$ & $(25.51)$ & $(40.84)$ \\
\hline $16-22$ & $-2.855^{*}$ & -2.858 & -2.722 & -2.929 \\
\hline & $(1.684)$ & $(312.2)$ & $(25.51)$ & $(40.84)$ \\
\hline $22-28$ & $-2.916^{*}$ & -2.737 & -2.893 & -2.848 \\
\hline & $(1.685)$ & $(312.2)$ & $(25.51)$ & $(40.83)$ \\
\hline $28-38$ & $-2.868^{*}$ & -2.787 & -3.097 & -3.006 \\
\hline & $(1.684)$ & $(312.2)$ & $(25.51)$ & $(40.84)$ \\
\hline $38-46$ & $-3.142^{*}$ & -2.917 & -3.090 & -3.044 \\
\hline & $(1.693)$ & $(312.2)$ & $(25.51)$ & $(40.84)$ \\
\hline $46-52$ & -2.802 & -2.570 & -2.476 & -2.447 \\
\hline & $(1.705)$ & $(312.2)$ & $(25.51)$ & $(40.84)$ \\
\hline $52-60$ & $-3.099^{*}$ & -2.846 & -2.309 & -2.608 \\
\hline
\end{tabular}


Table A.2 - Continued from previous page

\begin{tabular}{|c|c|c|c|c|}
\hline & $\begin{array}{c}\text { Women } \\
\text { aged 18-29 }\end{array}$ & $\begin{array}{c}\text { Men } \\
\text { aged 18-29 }\end{array}$ & $\begin{array}{c}\text { Women } \\
\text { aged 30-49 }\end{array}$ & $\begin{array}{c}\text { Men } \\
\text { aged 30-49 }\end{array}$ \\
\hline \multirow{3}{*}{$60-96$} & $(1.682)$ & $(312.2)$ & $(25.51)$ & $(40.84)$ \\
\hline & $-3.39^{* *}$ & -3.325 & -3.076 & -3.306 \\
\hline & $(1.699)$ & $(312.2)$ & $(25.50)$ & $(40.83)$ \\
\hline \multirow[t]{2}{*}{$96-104$} & -2.877 & -5.332 & -3.517 & -4.005 \\
\hline & $(1.807)$ & $(312.8)$ & $(25.50)$ & $(40.85)$ \\
\hline \multirow[t]{2}{*}{ 104- } & -5.145 & -3.927 & -3.950 & -4.11 \\
\hline \multirow{2}{*}{\multicolumn{5}{|c|}{ Variables }} \\
\hline & & & & \\
\hline \multirow[t]{2}{*}{ Children age $0-2$} & 0.061 & -0.036 & $0.097^{* *}$ & 0.006 \\
\hline & $(0.058)$ & $(0.065)$ & $(0.043)$ & $(0.044)$ \\
\hline \multirow[t]{2}{*}{ Children age $3-6$} & -0.047 & -0.019 & 0.000 & -0.005 \\
\hline & $(0.062)$ & $(0.094)$ & $(0.032)$ & $(0.040)$ \\
\hline \multirow[t]{2}{*}{ Children age $7-17$} & 0.040 & 0.060 & -0.040 & -0.002 \\
\hline & $(0.099)$ & $(0.138)$ & $(0.029)$ & $(0.035)$ \\
\hline \multirow[t]{2}{*}{ Age 18-24 } & 0.031 & -0.009 & & \\
\hline & $(0.045)$ & $(0.047)$ & & \\
\hline \multirow[t]{2}{*}{ Age 35-39 } & & & -0.031 & $-0.082^{* *}$ \\
\hline & & & $(0.037)$ & $(0.038)$ \\
\hline \multirow[t]{2}{*}{ Age $40-44$} & & & -0.052 & $-0.092^{* *}$ \\
\hline & & & $(0.043)$ & $(0.045)$ \\
\hline \multirow[t]{2}{*}{ Age $45-49$} & & & $-0.126^{* * *}$ & -0.058 \\
\hline & & & $(0.049)$ & $(0.048)$ \\
\hline \multirow[t]{2}{*}{ Married } & 0.045 & 0.062 & 0.017 & 0.047 \\
\hline & $(0.052)$ & $(0.064)$ & $(0.029)$ & $(0.034)$ \\
\hline \multirow[t]{2}{*}{ Primary school } & $-0.105^{* *}$ & -0.032 & -0.027 & $-0.089^{* *}$ \\
\hline & $(0.051)$ & $(0.047)$ & $(0.035)$ & $(0.037)$ \\
\hline \multirow[t]{2}{*}{ High school } & -0.085 & 0.008 & -0.054 & 0.022 \\
\hline & $(0.057)$ & $(0.066)$ & $(0.051)$ & $(0.062)$ \\
\hline \multirow[t]{2}{*}{ Short-term tertiary education (1-2 years ) } & -0.070 & -0.123 & -0.002 & 0.030 \\
\hline & $(0.105)$ & $(0.123)$ & $(0.062)$ & $(0.064)$ \\
\hline \multirow[t]{2}{*}{ Long- term tertiary education (3-6 years) } & 0.017 & -0.108 & -0.007 & 0.007 \\
\hline & $(0.078)$ & $(0.093)$ & $(0.043)$ & $(0.057)$ \\
\hline Immigrant from OECD countries & 0.144 & $0.181^{*}$ & 0.014 & 0.097 \\
\hline & $(0.094)$ & $(0.096)$ & $(0.074)$ & $(0.064)$ \\
\hline Immigrant from non-OECD countries & 0.156 & 0.144 & 0.100 & 0.095 \\
\hline & $(0.100)$ & $(0.102)$ & $(0.076)$ & $(0.073)$ \\
\hline Living in a bigger city & 0.081 & 0.068 & 0.053 & $0.093^{*}$ \\
\hline & $(0.056)$ & $(0.058)$ & $(0.050)$ & $(0.050)$ \\
\hline Living at the country & 0.072 & $0.108^{* *}$ & -0.013 & $0.073^{*}$ \\
\hline & $(0.049)$ & $(0.053)$ & $(0.041)$ & $(0.040)$ \\
\hline Years of work experiences & $0.333^{*}$ & 0.021 & 0.033 & -0.090 \\
\hline & $(0.191)$ & $(0.175)$ & $(0.074)$ & $(0.076)$ \\
\hline Years of work experiences ${ }^{2}$ & -1.482 & -0.390 & -0.014 & 0.222 \\
\hline & $(1.586)$ & $(1.333)$ & $(0.249)$ & $(0.244)$ \\
\hline Weeks of sickness benefit last year & 0.204 & 0.063 & 0.092 & $0.264^{* *}$ \\
\hline & $(0.156)$ & $(0.219)$ & $(0.087)$ & $(0.124)$ \\
\hline Weeks of sickness benefit two years ago & -0.132 & $0.814^{* * *}$ & 0.039 & $0.306^{*}$ \\
\hline & $(0.305)$ & $(0.277)$ & $(0.142)$ & $(0.165)$ \\
\hline Weeks of public inc. transfers last year & $-0.156^{* *}$ & -0.049 & -0.080 & -0.121 \\
\hline & $(0.073)$ & $(0.139)$ & $(0.055)$ & $(0.095)$ \\
\hline Weeks of public inc. transf. 2 years ago & $-0.132^{*}$ & $-0.384^{* * *}$ & $-0.184^{* * *}$ & $-0.223^{* * *}$ \\
\hline & $(0.079)$ & $(0.103)$ & $(0.054)$ & $(0.070)$ \\
\hline Weeks of pub. inc. transf. $3 \& 4$ years ago & -0.005 & 0.044 & -0.022 & $-0.144^{* *}$ \\
\hline & $(0.085)$ & $(0.097)$ & $(0.046)$ & $(0.061)$ \\
\hline UI fund construction & $0.109^{* *}$ & $0.122^{* * *}$ & $0.093^{* *}$ & $0.068^{*}$ \\
\hline & $(0.043)$ & $(0.046)$ & $(0.036)$ & $(0.040)$ \\
\hline UI fund metal & -0.247 & 0.154 & -0.180 & 0.111 \\
\hline & $(0.190)$ & $(0.118)$ & $(0.137)$ & $(0.096)$ \\
\hline UI fund production & -0.138 & 0.131 & -0.036 & 0.018 \\
\hline & $(0.443)$ & $(0.121)$ & $(0.211)$ & $(0.100)$ \\
\hline
\end{tabular}


Table A.2 - Continued from previous page

\begin{tabular}{|c|c|c|c|c|}
\hline & $\begin{array}{c}\text { Women } \\
\text { aged 18-29 }\end{array}$ & $\begin{array}{c}\text { Men } \\
\text { aged 18-29 }\end{array}$ & $\begin{array}{c}\text { Women } \\
\text { aged } 30-49\end{array}$ & $\begin{array}{c}\text { Men } \\
\text { aged 30-49 }\end{array}$ \\
\hline UI fund technicians & $-0.310^{* *}$ & -0.046 & $\begin{array}{l}0.050 \\
(0.124)\end{array}$ & -0.065 \\
\hline \multirow[t]{2}{*}{ UI fund trade } & -0.137 & 0.093 & -0.166 & -0.170 \\
\hline & $(0.184)$ & $(0.159)$ & $(0.128)$ & $(0.112)$ \\
\hline \multirow[t]{2}{*}{ UI fund services } & 0.024 & 0.076 & -0.078 & -0.099 \\
\hline & $(0.100)$ & $(0.098)$ & $(0.075)$ & $(0.087)$ \\
\hline \multirow[t]{2}{*}{ UI fund academics } & 0.077 & 0.012 & -0.043 & -0.099 \\
\hline & $(0.167)$ & $(0.157)$ & $(0.120)$ & $(0.119)$ \\
\hline \multirow[t]{2}{*}{ UI fund self-employed } & -0.222 & -0.138 & $-0.498^{* * *}$ & $-0.430^{* * *}$ \\
\hline & $(0.135)$ & $(0.131)$ & $(0.102)$ & $(0.102)$ \\
\hline \multirow[t]{2}{*}{ Other UI fund } & -0.075 & 0.165 & -0.099 & -0.060 \\
\hline & $(0.185)$ & $(0.168)$ & $(0.134)$ & $(0.131)$ \\
\hline \multirow[t]{2}{*}{ Union member } & $-0.394^{* *}$ & -0.010 & -0.041 & $-0.188^{* *}$ \\
\hline & $(0.156)$ & $(0.134)$ & $(0.083)$ & $(0.074)$ \\
\hline \multirow[t]{2}{*}{ Unemployment rate for UI fund } & -0.004 & 0.051 & 0.000 & $0.098^{*}$ \\
\hline & $(0.059)$ & $(0.067)$ & $(0.043)$ & $(0.051)$ \\
\hline \multirow[t]{2}{*}{ Second quarter } & $0.084^{*}$ & 0.048 & -0.013 & 0.062 \\
\hline & $(0.045)$ & $(0.050)$ & $(0.036)$ & $(0.040)$ \\
\hline \multirow[t]{2}{*}{ Third quarter } & 0.086 & 0.073 & 0.015 & 0.013 \\
\hline & $(0.053)$ & $(0.050)$ & $(0.039)$ & $(0.039)$ \\
\hline \multirow[t]{2}{*}{ Fourth quarter } & 0.164 & 0.381 & -0.008 & -0.035 \\
\hline & $(2.729)$ & $(2.396)$ & $(0.019)$ & $(1.805)$ \\
\hline \multirow[t]{2}{*}{ Year 2001} & $-0.638^{* * *}$ & $-0.760^{* * *}$ & $-0.501^{* * *}$ & $-0.501^{* * *}$ \\
\hline & $(0.068)$ & $(0.073)$ & $(0.053)$ & $(0.059)$ \\
\hline \multirow[t]{2}{*}{ Year 2002} & $-0.882^{* * *}$ & $-1.020^{* * *}$ & $-0.659^{* * *}$ & $-0.752^{* * *}$ \\
\hline & $(0.071)$ & $(0.073)$ & $(0.055)$ & $(0.060)$ \\
\hline \multirow[t]{2}{*}{ Year 2003} & $-0.542^{* * *}$ & $-0.639^{* * *}$ & $-0.353^{* * *}$ & $-0.441^{* * *}$ \\
\hline & $(0.062)$ & $(0.066)$ & $(0.049)$ & $(0.054)$ \\
\hline \multirow[t]{2}{*}{ Year 2004} & $-0.218^{* * *}$ & $-0.286^{* * *}$ & $-0.219^{* * *}$ & $-0.182^{* * *}$ \\
\hline & $(0.061)$ & $(0.067)$ & $(0.047)$ & $(0.053)$ \\
\hline \multicolumn{5}{|l|}{ Unobserved heterogeneity } \\
\hline \multirow[t]{2}{*}{ Employment 2} & -4.033 & 0.014 & -1.794 & -0.187 \\
\hline & $(30.76)$ & $(2,034)$ & $(536.2)$ & $(567.7)$ \\
\hline Meeting 2 & -0.466 & -0.012 & 0.528 & -0.627 \\
\hline & $(2.374)$ & $(1,656)$ & $(150.1)$ & $(1,499)$ \\
\hline Masspoint 2 & 5.484 & 4.731 & 3.802 & 4.188 \\
\hline & $(1,526)$ & $(47,309)$ & $(9,972)$ & $(1,725)$ \\
\hline Employment 3 & -0.434 & -5.019 & -0.382 & -0.123 \\
\hline & $(1,344)$ & $(355.8)$ & $(141.9)$ & $(2,519)$ \\
\hline Meeting 3 & 0.448 & 1.653 & 0.296 & -0.498 \\
\hline & $(3,538)$ & $(312.1)$ & $(58.46)$ & $(3,815)$ \\
\hline Masspoint 3 & 0.128 & 2.659 & 0.274 & -0.938 \\
\hline & $(1,564)$ & $(376,220)$ & $(17,840)$ & $(25,998)$ \\
\hline Employment 4 & 0.380 & -0.101 & -0.029 & 0.083 \\
\hline & $(7.752)$ & $(361.1)$ & $(208.5)$ & $(1,456)$ \\
\hline Meeting 4 & -0.816 & -0.512 & 0.081 & 0.125 \\
\hline & $(7.162)$ & $(341.3)$ & $(436.2)$ & $(1,809)$ \\
\hline Masspoint 4 & -0.527 & 0.040 & -0.547 & -1.481 \\
\hline & $(12,237)$ & $(3.090)$ & $(10,246)$ & $(36,375)$ \\
\hline Employment 5 & -0.233 & -0.133 & -0.202 & -1.558 \\
\hline & $(1,672)$ & $(284.6)$ & $(10.67)$ & $(22.78)$ \\
\hline Meeting 5 & 0.135 & 0.161 & -0.707 & 0.836 \\
\hline & $(1,646)$ & $(197.4)$ & $(22.76)$ & $(40.88)$ \\
\hline Masspoint 5 & 0.929 & -0.688 & 0.983 & 0.171 \\
\hline & $(1,567)$ & $(327.7)$ & $(16,574)$ & $(29,185)$ \\
\hline Employment 6 & -0.490 & -0.127 & -0.649 & 0.293 \\
\hline & $(145.9)$ & $(356.1)$ & $(38.27)$ & $(198.2)$ \\
\hline Meeting 6 & 0.783 & -2.430 & -0.388 & 0.308 \\
\hline & $(1,067)$ & $(312.8)$ & $(60.61)$ & $(106.9)$ \\
\hline Masspoint 6 & 0.498 & 1.172 & 0.689 & 0.391 \\
\hline
\end{tabular}


Table A.2 - Continued from previous page

\begin{tabular}{lcccc}
\hline & $\begin{array}{c}\text { Women } \\
\text { aged 18-29 }\end{array}$ & $\begin{array}{c}\text { Men } \\
\text { aged 18-29 }\end{array}$ & $\begin{array}{c}\text { Women } \\
\text { aged 30-49 }\end{array}$ & $\begin{array}{c}\text { Men } \\
\text { aged 30-49 }\end{array}$ \\
\hline \multirow{2}{*}{ Employment 7 } & $(4,260)$ & $(3,253)$ & $(10,126)$ & $(1,978)$ \\
Meeting 7 & 0.295 & -1.388 & -1.933 & -0.019 \\
& $(126.1)$ & $(356.1)$ & $(712.2)$ & $(89.29)$ \\
Masspoint 7 & 0.092 & -1.264 & 0.488 & -0.626 \\
& $(95.74)$ & $(312.2)$ & $(195.5)$ & $(127.6)$ \\
& -1.205 & 0.638 & -1.294 & -0.896 \\
\end{tabular}

Notes: Standard errors in parentheses; ${ }^{* *},{ }^{* *}$ and ${ }^{*}$ indicate significance at the $1 \%, 5 \%$ and $10 \%$ level, respectively. 